\title{
Seafood Safety, Potential Hazards and Future Perspective
}

\author{
Suhendan $\mathrm{Mol}^{1, *, \#}\left(\mathbb{D}\right.$, Serap Coşansu ${ }^{2, \#}(\mathbb{D})$
}

\author{
${ }^{1}$ Istanbul University, Faculty of Aquatic Sciences, Department of Fisheries and Seafood Processing Technology. \\ Kalenderhane Mh., Onaltı Mart Şehitleri St, No: 2 P.K 34134 Vezneciler Fatih, İstanbul, Türkiye. \\ ${ }^{2}$ Sakarya University, Engineering Faculty, Department of Food Engineering. 54187 Sakarya, Türkiye. \\ \#These authors share the first authorship.
}

\section{How to cite}

Mol, S., Coşansu, S. (2022). Seafood Safety, Potential Hazards and Future Perspective. Turkish Journal of Fisheries and Aquatic Sciences, 22(6), TRJFAS20533. http://doi.org/10.4194/TRJFAS20533

\section{Article History}

Received 28 August 2021

Accepted 27 January 2022

First Online 08 February 2022

\section{Corresponding Author}

Tel.: +902124555700

E-mail: suhendan@istanbul.edu.tr

\section{Keywords \\ Fish \\ Health risk \\ Pathogen \\ Climate change \\ Covid-19}

\section{Introduction}

Seafood is an essential food of public health significance. A significant part of consumers is well aware of the nutritional value of fish. They find fish healthier than red meat considering its low cholesterol content. Besides, in many countries, people hesitate to consume chicken because of the unhealthy farming conditions. Some diseases such as mad cow and avian flu also motivate people to consume seafood. However, seafood consumption is generally far below the recommended amount across the world, except Japan, Norway, and Arctic regions, and consumers mainly recognize that they eat less seafood than they should. Seafood consumption has been associated with reducing stroke, cardiovascular disease, inflammatory diseases, hypertension, depression, and some cancers. The risk of Alzheimer's disease, arthritis, and attentiondeficit/hyperactivity disorder (ADHD) may also be decreased by regular seafood consumption. Vitamin $D$, found in fish, is vital for bone development since it is essential for bone mineralization. Low to medium doses of selenium intake by food supports the human body by preventing diseases. Most of the fish species are good sources of this essential trace element. Selenium is essential for the synthesis of selenocysteine, needed for the activities of selenoenzymes. Since these enzymes play important roles in fetal brain development and growth, fish consumption of expectant women is beneficial for the neurodevelopmental of the fetus (Nicholas et al., 2019). Therefore, it is generally recommended to consume seafood at least twice a 
week, and consumers are usually motivated to eat seafood considering its health benefits. Eating this amount of fish has been reported to reduce (23-25\%) risk of death from coronary heart disease than people eating very small amounts. The people eating fish once a week, this risk has been reported to reduce 15\% (KrisEtherton et al., 2002).

Seafood is very tender, digestible, and convenient for the consumption of all ages since it has very little connective tissue. They contain high-quality proteins and are rich in essential amino acids. They are also significant sources of $n-3$ polyunsaturated fatty acids (PUFA), which can reduce the risk of cardiovascular diseases and contribute to normal neurodevelopment in children. Chronic Heart Disease (CHD) is one of the biggest health problems facing people worldwide. Omega-3 fatty acids, which have anti-inflammatory, antithrombotic and antiatherogenic effects, protect against CHD. Ameen et al. (2020) studied the connection between fish consumption and CHD mortality. They reported that the CHD mortality rate decreased significantly after a certain period when fish consumption increased. Eicosapentaenoic acid (EPA) and docosahexaenoic acid (DHA) are the primary PUFA's since they can lower blood pressure, decrease serum triglycerides, thrombotic tendency, and inflammation.

The other essential components are micronutrients such as vitamins $A, D, E, K$, and $B_{12}$ and minerals such as calcium, selenium, phosphor, sodium, potassium, magnesium, iodine, iron, copper, fluorine, cobalt, and zinc. These are essential to maintain normal physiological functions in human beings. All fish and shellfish are good sources of calcium and magnesium and are recommended to be consumed to provide most minerals needed by the human body. Fish and shellfish provide multi-health benefits when consumed in recommended amounts (Nurnadia et al., 2013). The ratios of principal components (water, protein, lipids, minerals, and vitamins) of the flesh show remarkable variations depending on the species, catching area, maturity, nutrition, and catching season. The lipid content of a fatty fish could be equal to or sometimes lower than that of a lean fish. Since the factors such as the lipid or water contents of the raw material affect the taste, texture, and shelf life of the product, the chemical composition of seafood is important for fish processors to maintain standard product quality. The postharvest biochemical and microbiological changes in fish are significantly affected by the factors such as the circumstances of capture, initial bacterial contamination of the catch, conditions during transport and storage (Sikorski et al., 1990). As well as these beneficial properties, fish may also pose some potential natural or anthropogenic hazards, and it is one of the most perishable foods (Figure 1). These characteristics must be taken into account during transportation, marketing and processing of the fish to avoid potential hazards while enjoying the benefits of the fish.

\section{Seafood Consumption Trends and Future Perspective}

In the twenty-first century, urbanization, increased mental work, and learning about the direct relationship between food and health have led to a change in dietary habits worldwide. The greater participation of women in the workforce, structural changes in demographics, health and environmental concerns have affected consumer preferences. Consumer awareness has increased on many issues such as production conditions, marketing, preservation or packaging methods, and the origin of the food. The preference for food type has also changed, and the demand for more nutritious and healthy food has increased. Revealing the change in consumer preferences is important for ensuring the future perspective. Bairagi et al. (2020) studied the changes in food consumption, and implications have been made for the future food supply system. The largest expenditure elasticity has been reported for fish demand, and it was concluded that there is a transformation in the food demand system. Fish consumption is expected to increase in developing countries due to urbanization, population and income growth. The fast expansion of aquaculture is the only scenario that will drop real prices of low-value fish, and most of the fish on the table will come from aquaculture very soon. As the demand for fishery products increases, technology will also gain more importance. It is very important to develop technologies to deliver healthy fish to consumers under hygienic conditions, ensure sustainability due to increasing demand, and reduce the environmental damage caused by increased fisheries. Food safety systems for seafood imports should be rationalized, product classifications should be harmonized, policies should be developed on ecolabeling and food safety. Policy makers must ensure that fish resources will be protected, sustainable and accessible to poor people (Delgado et al., 2020). Eating fish has multiple benefits for children, adults and the elderly. Fish consumption is associated with a lower incidence of preterm birth, leading to perinatal mortality and morbidity. So, consuming $\geq 350 \mathrm{~g} /$ week of fish and shellfish has been advised for pregnant women. Increased fish intake may also support longer gestation and prevent preterm birth (Wang et al., 2021). Since nutrition is important for brain and physical development, it is important for the health of future generations to include fish in the nutrition of children and young people. Nevertheless, instead of highlighting only the benefits of fish, it is necessary to diversify new products that young people accept and introduce them according to today's promotion and communication tools. Increasing obesity in developed countries is another factor that necessitates the orientation towards fish consumption. Understanding the factors associated with fish consumption is also crucial to implementing successful strategies to increase fish consumption, fish sales and exports. In some countries, fish has been 


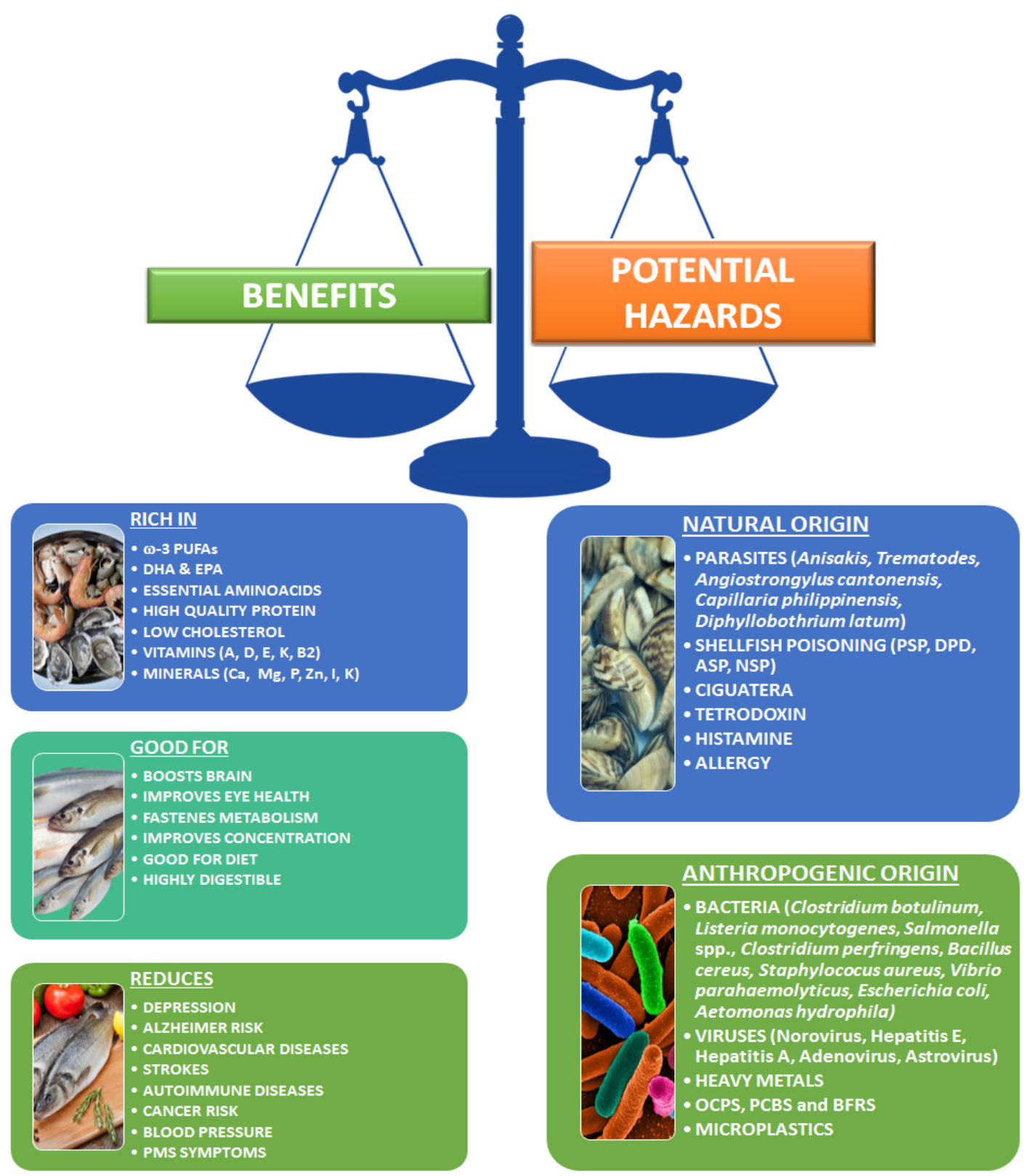

Figure 1. Benefits and potential hazards due to seafood consumption.

considered a luxury product. This affects the consumption habits of the population and causes the fish to take a small place on the table to meet the protein need. On the other hand, many developed countries, including Japan, where fish consumption is already high, have implemented health policies that encourage fish consumption. It has been noted that experiences making people feel closer to fish, such as contributing to fishing activity or eating fish during a festival, are more effective than campaigns only giving information (Gangs $\varnothing, 2021$ ).

Although campaigns and politics to increase fish consumption are very important, it should not be forgotten that the "availability", which includes the price and sustainability, is important for the consumer. Availability is among the main reasons for preferring chicken and pork meats instead of fish products. For this reason, consumers should be better informed about aquaculture fish (Kitano and Yamamoto, 2020). It is crucial to understand factors affecting fish consumption habits to implement successful health policies and strategies to increase fish consumption in public or export fish products to various countries. Despite all the health benefits of fish, simply saying "fish is a healthy food, eat fish" is not satisfactory for many consumers today. New expectations are emerging among the consumers who are aware that the world's limited resources are running out. The consumer has realized the importance of sustainability for the future and tended to food with a low negative environmental footprint, as much as possible (Gangs $\varnothing$, 2021). Today, it is increasingly possible for the consumer to access details such as where the fish is caught or cultured, the supplier company, and the product's characteristics. The new generation knows how to access this information and find ordinary to question all details about their food. 
This situation makes it necessary for product suppliers and manufacturers to act in accordance with the expectations of the new consumer. Traceability became more popular after the Covid-19 outbreak. The pandemic has increased the interest of consumers in the origin of their food. As a result, mechanisms that assure the production process and origin of fishery products are gaining more importance. Therefore, the traceability of seafood products will become a popular assurance mechanism in the seafood industry (Farradia and Sunarno, 2020).

Covid-19 has impacted people's lives around the world, creating rapid and massive changes in every industry. After the Covid-19 pandemic, many consumers worried about unpackaged products being contaminated with the coronavirus. The fear of contamination from the surfaces also increased the need for hygiene and led to packaged products. These were the most obvious effects of the pandemic in the food field (Gangs $\varnothing, 2021$ ). The Covid-19 pandemic has led consumers to buy online, and new behaviors have developed, including seafood. The change in consumer habits did not only limit the way of purchasing; eating outside has also decreased significantly. Online delivery, food delivery or takeout has increased more than ever before. While online marketing of fish and fish products is still new, seafood processing and aquaculture businesses will need to adapt to changing preferences and the new normal after the Covid-19 pandemic (Farradia and Sunarno, 2020).

The fact that food resources are decreasing in the face of the increasing population reveals the importance of sustainability and the orientation to alternative products. An exciting and somewhat frightening development is "lab-grown" - proteins. The stem cells are taken from animals and cultivated in the lab to produce lab-grown protein. Therefore, the number of animals used as human food will be reduced. The other step will be producing it without real animal cells. Insects also promise an important source in meeting their protein needs. Insects are already consumed as food in some societies and offer a much easier alternative to lab-grown food. Insects convert what they eat into energy very efficiently, use less space and have lower emissions than other animal foods (Gangs $\varnothing$, 2021). Of course, changing consumer attitudes will be challenging for such products. However, the food industry will need to develop technologies that will adapt to the changing conditions of our world.

\section{Potential Hazards}

Parasites, shellfish poisonings, Ciguatera, Tetrodotoxin, Histamine, allergens, pathogens, viruses, heavy metals, OCPs, PCBs and BFRs and microplastics have been recognized as major potential hazards to human health due to seafood consumption. Some of the reported outbreaks associated with seafood consumption are presented in Table 1.

\section{Parasites}

The parasite risk should be considered when raw, undercooked, or marinated fish are consumed. This risk is eliminated either by cooking or freezing fish before consumption.

Anisakis Nematodes: Anisakidae nematodes are important sources of parasite-borne diseases in humans, and their larvae can cause anisakiasis. They use fish and warm-blooded vertebrates as hosts, and marine mammals are generally their final hosts. The usual symptoms of illness are stomach pain, nausea, vomiting, and various abdominal pains. Diagnosis is not easy since these symptoms are similar to many other diseases. The larvae of Anisakis simplex are found in many marine fish. The immature larvae do not cause any significant reaction in humans, but taking advanced stage larvae into the human body results in various symptoms, such as epigastric pain after ingesting infected fish. Its larvae die at about $60^{\circ} \mathrm{C}$. So, generally, no risk is pronounced due to consuming sufficiently cooked fish or processed seafood that includes a cooking step. However, it is best to freeze the fish first when preparing raw or lightly marinated fish. These larvae die within 24 hours between -17 and $-20^{\circ} \mathrm{C}$, but they are resistant to salting, marinating, spices and chemicals. When served raw, it is also recommended to freeze the fish, but thawing conditions are critical in preserving quality. Podolska et al. (2019) studied the effect of freezing to kill $A$. simplex larvae on fish. They reported that the nature of fish is important and the freezing temperature because at $15^{\circ} \mathrm{C}$, they killed all $A$. simplex larvae in the cod fillet, but not all of them in the herring.

Angiostrongylus cantonensis: Angiostrongylus cantonensis is more common in terrestrial animals such as rats and is the most common infectious cause of meningitis. It is a neurotropic helminth. Patients with meningitis caused by Angiostrongylus cantonensis reported consuming fish and other seafood. Humans may be infected with Angiostrongylus larvae due to consuming crabs, shrimp, frogs, freshwater snails, and slugs. There is no standard of treatment for the infected people; the symptoms may be treated using analgesics, corticosteroids, anthelmintic or antiparasitic drugs (Rothe and Katchanov, 2020).

Capillaria philippinensis: It is the reason intestinal capillariasis causes diarrhea in humans. It is reported that the infection is caused by eating raw freshwater fish containing nematode parasite eggs. Unembryonated eggs of $C$. philippinensis are transferred from the feces of the infected host to the soil or water, then to fish. In the intestines of fish, eggs hatch, and larvae grow. When poorly cooked or raw fish is consumed, the larvae grow to an adult in the intestine of humans (Belizario and Totañes, 2014).

Diphyllobothrium latum: Hosts mostly in crustacea and fish, matures in humans, and causes weakness and anemia. The symptoms include abdominal discomfort, diarrhea or constipation, and weight loss. 
Table 1. The outbreaks associated with seafood consumption

\begin{tabular}{|c|c|c|c|c|c|}
\hline Outbreak agent & $\begin{array}{l}\text { Location } \\
\text { (Year) }\end{array}$ & Associated seafood & $\begin{array}{c}\text { Symptoms/Clinical } \\
\text { Manifestation }\end{array}$ & Case Number & Reference \\
\hline C. botulinum toxin & China (2019) & Vacuum-packed salted fish & $\begin{array}{c}\text { Nausea, vomiting, dysphagia, } \\
\text { pain }\end{array}$ & 4 cases ( 1 death) & $\begin{array}{l}\text { Min et al. } \\
(2021)\end{array}$ \\
\hline V.parahaemolyticus & $\begin{array}{c}\text { China } \\
(2010-2014)\end{array}$ & $\begin{array}{l}\text { Aquatic products including } \\
\text { shrimp, fish, clams, } \\
\text { mollusks }\end{array}$ & $\begin{array}{l}\text { Hospitalizations without } \\
\text { death }\end{array}$ & $\begin{array}{l}339 \text { total cases in } \\
27 \text { outbreaks }\end{array}$ & $\begin{array}{l}\text { Chen et al. } \\
\text { (2017b) }\end{array}$ \\
\hline $\begin{array}{l}\text { Listeria } \\
\text { monocytogenes }\end{array}$ & $\begin{array}{c}\text { Sweden } \\
(1994-1995)\end{array}$ & $\begin{array}{l}\text { Vacuum-packed gravad and } \\
\text { cold-smoked fish }\end{array}$ & Not mentioned & 9 cases ( 2 deaths) & $\begin{array}{l}\text { Tham et al. } \\
\text { (2000) }\end{array}$ \\
\hline $\begin{array}{l}\text { Listeria } \\
\text { monocytogenes }\end{array}$ & $\begin{array}{c}\text { Denmark } \\
(2013-2015)\end{array}$ & Smoked fish & Sepsis, meningitis & $\begin{array}{l}20 \text { total cases in } \\
\text { two outbreaks ( } 8 \\
\text { deaths including } \\
\text { one } 38 \text {-weeks } \\
\text { fetus) }\end{array}$ & $\begin{array}{l}\text { Lassen et al. } \\
\qquad(2016)\end{array}$ \\
\hline Salmonella serotypes & $\begin{array}{l}\text { United States } \\
\qquad(2015)\end{array}$ & $\begin{array}{l}\text { Sushi prepared using frozen } \\
\text { raw tuna }\end{array}$ & Not mentioned & 65 cases & $\begin{array}{l}\text { Hassan et al. } \\
\text { (2018) }\end{array}$ \\
\hline Histamine poisoning & $\begin{array}{l}\text { Italy (2013- } \\
\text { 2020) }\end{array}$ & $\begin{array}{l}\text { Raw and cooked anchovy, } \\
\text { canned tuna, raw tuna, } \\
\text { cod, swordfish, shrimp } \\
\text { tails, langoustine, }\end{array}$ & $\begin{array}{l}\text { Diffuse erythema, dyspnea, } \\
\text { tachycardia, urticaria, } \\
\text { heartbeat, headache, } \\
\text { vomiting, abdominal pain, } \\
\text { dysentery }\end{array}$ & $\begin{array}{l}6 \text { outbreaks (The } \\
\text { number of cases } \\
\text { is not specified) }\end{array}$ & $\begin{array}{l}\text { Annunziata et } \\
\text { al. (2022) }\end{array}$ \\
\hline Ciguatera toxin & $\begin{array}{c}\text { Germany } \\
\text { (2012) }\end{array}$ & Tropical fish & Neurological symptoms & 20 cases & $\begin{array}{l}\text { Friedemann } \\
\qquad(2016)\end{array}$ \\
\hline Tetrodotoxin (TTX) & $\begin{array}{l}\text { Bangladesh } \\
\text { (2008) }\end{array}$ & Pufferfish & $\begin{array}{c}\text { Perioral paraesthesia, } \\
\text { vomiting, dizziness, headache, } \\
\text { paralysis }\end{array}$ & $\begin{array}{l}141 \text { total cases in } \\
3 \text { outbreaks }\end{array}$ & $\begin{array}{l}\text { Islam et al. } \\
\text { (2011) }\end{array}$ \\
\hline Ciguatera toxin & $\begin{array}{l}\text { Hong Kong } \\
\text { (2004) }\end{array}$ & $\begin{array}{l}\text { C. undulatus, E. coioides, } P \text {. } \\
\text { areolatus, } P \text {. leopardus }\end{array}$ & Not mentioned & $\begin{array}{l}247 \text { total cases in } \\
65 \text { outbreaks }\end{array}$ & $\begin{array}{l}\text { Wong et al. } \\
\qquad(2005)\end{array}$ \\
\hline Ciguatera toxin & $\begin{array}{l}\text { Moorea } \\
\text { Island, French } \\
\text { Polynesia } \\
\text { (2007-2013) }\end{array}$ & $\begin{array}{l}\text { C. striatus, L. monostigma, } \\
\text { Scarida, Mugilidae, C. } \\
\text { undulates, Balistoides spp., } \\
\text { Caranx spp., C. argus, } \\
\text { Lethrinus spp. }\end{array}$ & Not mentioned & 97 cases & $\begin{array}{l}\text { Morin et al. } \\
\qquad(2016)\end{array}$ \\
\hline Unknown toxin & $\begin{array}{l}\text { Brazil (Date is } \\
\text { not specified) }\end{array}$ & Cooked fish (Seriola spp.) & Rabdomyolysis (Haff Disease) & 2 cases & $\begin{array}{l}\text { Almeida et al. } \\
\qquad(2019)\end{array}$ \\
\hline $\begin{array}{l}\text { Palytoxin-like } \\
\text { compounds }\end{array}$ & $\begin{array}{l}\text { Salvador, } \\
\text { Brazil (2016- } \\
\text { 2021) }\end{array}$ & $\begin{array}{c}\text { Seriola sp., Myceteroperca } \\
\text { sp. }\end{array}$ & Rabdomyolysis (Haff Disease) & $\begin{array}{l}93 \text { total cases in } \\
\text { two outbreaks } \\
\text { (one death) }\end{array}$ & $\begin{array}{l}\text { Cardoso et al. } \\
\qquad(2022)\end{array}$ \\
\hline Saxitoxin & $\begin{array}{l}\text { Tailand } \\
\text { (2008) }\end{array}$ & $\begin{array}{l}\text { Soup containing the fish } \\
\text { balls }\end{array}$ & $\begin{array}{c}\text { Facial diplegia, dizziness, dry } \\
\text { mouth, visual sensitivity, } \\
\text { numbness, headache, } \\
\text { myalgia, nausea, vomiting }\end{array}$ & 300 cases & $\begin{array}{l}\text { Chankrachang } \\
\text { et al. (2009) }\end{array}$ \\
\hline
\end{tabular}

Diphyllobothrium latum, the fish tapeworm, has been expressed as a human parasite of extreme fertility. Increased cases of diphyllobothriasis due to Diphyllobothrium latum in France, Switzerland, and Italy has been reported as a result of a change in eating habits to consume raw or undercooked freshwater fish (Gustinelli et al. 2016). Control of fecal contamination of water, informing consumers about proper eating habits, and applying effective parasite inactivation methods for fish from risky areas are the critical factors of prevention.

Trematodes: Zoonotic trematodes pose a foodborne public health issue. Their first hosts are the mollusks, the second hosts are Crustacea, and their final hosts are humans or animals consuming raw fish. People may be infected due to regular consumption of raw, undercooked, or insufficiently cooked fish, and 40 million people worldwide are exposed to some diseases due to infections with trematodes. In most cases, the symptoms such as fever, abdominal pain, or weakness may be seen, but heavy infections of the consumer may occur if the fish contain a high amount of trematodes.
Diseases such as hepatomegaly, pancreatitis, cholangiocarcinoma, biliary calculi, cholelithiasis, cholangitis, and liver cirrhosis may occur. Good aquaculture practices were reported to reduce infection doses in cultured fish (Cech et al., 2021).

\section{Shellfish Poisoning}

Paralytic Shellfish Poisoning (PSP): Paralytic shellfish toxins (PST), also called saxitoxins, are the neurotoxins produced by marine dinoflagellates and freshwater cyanobacteria. After eating poisoned shellfish, crustaceans, or mollusks, the toxin may affect the nervous system of the consumer (Li and Persson, 2020). The most known organisms associated with PSP are Gonyaulax catenella, Gonyaulax tamarensis, Gymnodium brevis, and Gymnodinium catenatum. Mollusks such as mussels, scallops, and oysters, fed by filtering the nutrients in the water, are the primary source of this toxin for humans. The toxin formation in the mollusks takes a few days, but the excretion takes a few weeks. Ingestion of small doses of the toxin can 
cause tenderness and swelling of the lip corners in consumers, but it can cause paralysis and death in higher amounts. Its antidote is unknown, and there are 18 known PSP toxins (such as STX-saxitoxin, NEOneosaxitoxin, GTX-gonyautoxin, etc.). It cannot be removed by cooking or other processing methods. The increased anthropogenic activities and climate change lead to increase hazardous algal blooms. The need for proper regulation about Paralytic Shellfish Toxins has been reported as a crucial issue for the bivalve aquaculture industry in the northeastern Atlantic region (Karlson et al., 2021).

Studies continue on new methods for monitoring PSP toxin in seafood. Tian et al. (2021) examined the applications of using biosensors for PSP monitoring in seafood as they are cheap, convenient, effective, and efficient. They classified biosensors considering their detection principles as electrochemical sensors, acoustic devices, optical devices, field-effect transistors, and electrochemiluminescence. Micro-nano biosensors are predicted to be critical for food safety, monitoring, and food trade, with their role in detecting shellfish toxins. The pre-chromatographic method named 'Lawrence' has been described by Vale et al. (2021) to detect saxitoxins in bivalves. It was found to be successful in detecting saxitoxins originating from Gymnodinium catenatum, and further processing is not needed for samples containing low toxin amounts. But it was regarded found very labor-intensive.

Diarrhetic Shellfish Poisoning (DSP): Diarrhetic shellfish poisoning (DSP) toxins are produced by various phytoplankton, such as dinoflagellates Prorocentrum and Dinophysis. Okadaic acid (OA) and its derivative dinophysis toxin (DTX) are the most determined toxicants of diarrheal shellfish poisoning toxins. Toxins accumulate in shellfish tissues and cause food intoxication in humans after consumption. Symptoms such as diarrhea, vomiting, nausea, and abdominal pain occur within a few hours after consumption (Elal Muş and Çetinkaya, 2017). Between May and June 2019, a DSP outbreak was reported due to consuming mussels in the United Kingdom. High levels of heat-stable okadaic acid (OA) toxins were reported in mussels (Nick et al., 2019). Today, new methods for detecting DSP toxins continue to be developed. Li et al. (2018) proposed a biosensor to detect DSP and PSP toxins by monitoring the viability and electrophysiology of cardiomyocytes and defined it as a promising and useful method. Chen et al. (2017a) developed a new method using semi-preparative high-performance liquid chromatography-mass spectrometry and macroporous resin, high-speed counter-current chromatography/mass spectrometry to purificate two typical diarrhetic shellfish poisoning toxins from toxinproducing marine microalgae.

Amnesic shellfish poisoning (ASP): It is caused by domoic acid, a neurotoxic amino acid. It shows the typical symptoms seen in many food poisonings: loss of balance, headache, disorientation, and gastrointestinal disorders. Similarly, this occurs as a result of the consumption of shellfish products. The most characteristic symptom is loss of short-term memory, hence has been named Amnesic poisoning. While success is observed in the early treatment of domoic acid-related toxications, irreversible conditions such as memory loss may be encountered in treating delayed cases (Schroeder et al., 2015). The occurrence of domoic acid in shellfish from Great Britain was assessed between 2008-2017. The frequency of toxin events was reported to be increased during this period. While most cases were related to Pseudo-nitzschia blooms, Pseudonitzschia cell densities did not correlate with domoic acid levels in shellfish tissues. Therefore, a direct relationship between shellfish toxicity and cell abundance has not been reported. The need for detailed taxonomic discrimination of the genus Pseudo-nitzschia was highlighted for a more accurate prediction of shellfish toxicity (Rowland-Pilgrim et al., 2019).

Neurotoxic shellfish poisoning (NSP): Brevetoxins are mainly produced by Karenia brevis, a dinoflagellate, and consumption of brevetoxin-contaminated mollusks results in Neurotoxic shellfish poisoning (NSP). Karenia brevis bloom is commonly referred to as the Florida red tide and occurs along the Gulf of Mexico. This algal bloom results in annually reported cases of NSP in the United States. In 1987, forty-eight people who ate oysters after a red tide in North Carolina showed gastrointestinal and neurological symptoms. The rate of illness attacks significantly increased with the number of oysters consumed. In 2006, a large outbreak of more than 20 cases of NSP was recorded in the US, mainly due to oyster consumption. However, there have been no increasing toxicity cases over the past 30 years (Anderson et al., 2021). Abraham et al. (2021) reported that gastropod-seafoods might transfer brevetoxins to humans during the blooms of Karenia brevi, and they should be monitored to track NSP risk. They also reported brevetoxin 3 (BTX-3) as a marker of brevetoxin exposure in gastropod-seafoods.

Azaspiracid Shellfish Poisoning (AZP): Azaspiracid toxins (AZAs) are very recently discovered marine biotoxins, and they lead to Azaspiracid Shellfish Poisoning (AZP) when consumed. The symptoms of AZP are stomach cramps, vomiting, nausea, and diarrhea. These symptoms are similar to DSP's, but neurotoxic symptoms may also occur. The first identification of Azaspiracids as a causative shellfish poisoning was in 1995. The poisoning occurred in The Netherlands after eating mussels imported from Ireland (McMahon and Silke, 1996). After then, these toxins were detected in various shellfish species around the World (Bresnan et al., 2021; Karlson et al., 2021). Azaspiracid Shellfish Poisoning is not very common, and long-term illnesses due to AZP have not been reported. 


\section{Ciguatera Poisoning}

Ciguatera poisoningis a neurological disease caused by aquatic products contaminated by organisms naturally found in the marine environment. Benthic dinoflagellates of genera Gambierdiscus and Fukuyoa produce lipid-soluble ciguatoxins (CTXs) resistant to heat. Ciguatera poisoning is phycotoxin-related and affects 10,000 - 50,000 people per year. Symptoms of poisoning are mild paralysis, gastrointestinal disturbances, neurological problems, and cardiovascular problems. The death may be seen in extreme cases. There is a lack of knowledge about the prevalence of Ciguatera due to the limited epidemiological data, insufficient recognition of symptoms, and inadequacy of reported cases in endemic regions. Recently, global initiatives have emerged to provide systems for data collection, risk assessment, and patient management of Ciguatera poisoning cases (Chinain et al., 2021). Kusche and Hanel (2021) indicated the importance of proper labeling of tropical fish to prevent ciguatera intoxication. They reported that all samples $(n=103)$ of red snapper (Lutjanus malabaricus) were mislabeled, and most of them were problematic concerning ciguatera. Travelers should be informed to avoid eating ciguatoxic fish species on their travels to the tropics to prevent ciguatera fish poisoning. Ciguatera poisoning due to imported fish has also started to be seen as an emerging health issue. Doctors should be aware of the symptoms and treatment of Ciguatera poisoning.

\section{Tetrodotoxin}

Tetrodotoxin (TTX) was firstly isolated from pufferfish, a Japanese specialty food (Hameed et al., 2021). It may also exist in Central American frogs, gastropods, and some crabs (Simmons, 2007). Australian blue-ringed octopus (Whitelaw et al., 2019) and mussels (Bordin et al., 2021) were also reported to contain this toxin. The toxin is found in the liver, intestines, gonads, and skin. When the toxic parts are eaten, the toxin causes skeletal muscle paralysis and may cause death. The presence of this toxin in an organism is mainly dependent on the presence of bacteria capable of synthesizing toxins, such as Pseudoalteromonas haloplanktis subsp. tetraodonis and Vibrio sp., especially $V$. alginolyticus. Increased frequency of the reports on the presence of TTX in various gastropods and bivalves has been reported. Increased monitoring is needed to determine whether it results from advanced detection methods or the prevalence of the toxin (Biessy et al., 2019). This toxin has started to spread to different regions over time.

The Suez Canal leads to the "Lessepsian Migration" that transports more than three hundred species from the Red Sea to the Mediterranean Sea. This migration brings some risks not naturally found in the Mediterranean Sea. The population of a Lesepsian species Lagocephalus sceleratus increased in the
Mediterranean Sea as there were no predators. This fish belongs to Tetraodontidae originated from the Red Sea. The first toxicity assessment of $L$. sceleratus, Lessepsian pufferfish, caught in European coastal waters (Aegean Sea, Greece) has been reported by Katikou et al. (2009). This species was caught from the Southeast Aegean Sea in 2007. Toxicity of internal organs has been reported above the concentrations that can cause death in adult humans. After that, another first report of TTX due to a different pufferfish species (Torquigener flavimaculosus) in the Mediterranean Sea was reported by Kosker et al. (2018). This report shows that Lessepsian puffer fish species passing through the Suez Canal increase the toxin risk in the Mediterranean Sea. Muscle tissues, skin, gonads, liver, and intestines were examined, and high TTX concentrations were reported in all these body parts. This species is highly toxic and should never be consumed by humans. It has been reported that puffer fish species are rapidly increasing harmful species in the Mediterranean Sea and are dangerous for human health. In a recent study (Akbora et al., 2020), 40\% of tissues of silver cheeked pufferfish (L. sceleratus) caught from Cyprus were reported to contain the toxin above the limit $(2.2 \mu \mathrm{g} / \mathrm{g})$. In Japan, 2 mg equivalent of (eq) $T T X / k g$ was established as the limit for TTX. On the other hand, any fish from the Tetraodontidae family or fish products derived from it are not marketed under current EU legislation (EC, 2004).

\section{Histamine Formation}

Some of the factors contributing to spoilage are specific to species. Fatty fish such as tuna, mackerel, sardine, bonito, and anchovy are rich in histidine. Histamine can accumulate when these species are exposed to temperature abuse conditions during storage and/or transportation. The formation of histamine is negligible when the fish is refrigerated. Therefore, maintenance of the cold chain is essential during transport, storage, and processing. The microbial population of fresh fish contains producers of histamine decarboxylase enzyme (FDA, 2021). The members of Enterobacteriaceae family, especially Morganella morganii, some strains of Klebsiella pneumonia, and Hafnia alvei produce decarboxylases. Therefore, histamine is produced as well as the other biogenic amines such as putrescine, cadaverine, spermine, and spermidine. Histamine poisoning is dangerous for the consumer since it occurs without any outward indications of spoilage. It may cause dilation of blood vessels, hypotension, itching, flushing, and headache. Due to these adverse effects of histamine on human health, it has become essential to use new, fast and sensitive analytical methods for histamine determination in fish. The current methods such as thinlayer chromatography (Kounnoun et al., 2020), capillary zone electrophoresis with UV-detection (Felisiak et al., 2019), high-performance liquid chromatography with 
fluorescence detection (Ishimaru et al., 2019), liquid chromatography-tandem mass spectrometry (Ochi, 2019), surface-enhanced Raman Spectroscopy (Janči et al., 2017), square wave stripping voltammetry (Yilmaz and Inan, 2015), and temperature-controlled ionic liquid-based microextraction (Elik, 2021) have been studied to determine histamine in fish.

The processes such as freezing, cooking, chilling, pasteurizing, etc., are ineffective on histamine. So, its formation should be prevented by rapid chilling and cold chain maintenance (Lampila and McMillin 2012). Hygiene is also vital during storage and transport since the risk of histamine poisoning is more probable when the fish is contaminated with histamine decarboxylaseproducing bacteria (Sikorski et al., 1990). It has been recommended to reject the fish lot if any individual is found with a histamine concentration above or equal to 50 ppm (FDA, 2021).

\section{Seafood Allergies}

Seafood, especially shellfish, is one of the main reasons for food allergy. Immunoglobulin E (IgE)-related seafood allergies are the most known types of ones. Commercial allergen components and extracts of various seafood are used to identify IgE in serum. Seafood allergy is also one of the most common and deadly allergies. Crustaceans, especially shrimp, are the most studied group concerning seafood allergies. Tropomyosin, arginine kinase, myosin light chain, and sarcoplasmic calcium-binding protein are involved in allergic reactions. For shellfish, tropomyosin has been considered the most critical allergen, and it is the first allergen defined in seafood. This allergen is thermostable and does not decompose during digestion. The secondly identified allergen is arginine kinase, recognized in 2008. It is responsible for respiratory diseases in humans since it is volatile. Myosin light chain is the other allergen identified in 2008. It is a resistant but minor allergen. Sarcoplasmic Calcium-binding Protein is a stable and very resistant allergen, mainly related to crustaceans (Gelis et al., 2020). For finfish, the major allergen for finfish is parvalbumin. Parvalbumin and collagen are the causative agents of fish allergy, and they are also highly cross-reactive pan-allergens. Since there is no definitive treatment for shellfish allergy, the only way for allergy sufferers is to avoid consumption. Even though immunotherapy may help cure allergies such as peanut or egg, there is a lack of knowledge about treating shellfish allergy. The most significant barriers to curing shellfish allergy are the cross-reactivity of tropomyosins in crustaceans and the contribution of other allergens (Davis et al., 2020). A limited diagnosis could be made to only a few species and allergens for seafood. Today, there is no licensed immunotherapy to cure seafood allergies. Work-related allergy is the other significant problem that may threaten workers of the fishery industry. The employee working at seafood preparation, quality control, and sale steps may have allergic issues. In terms of insurance law, the risk of seafood allergy should be considered.

\section{Pathogenic Bacteria}

The presence of pathogenic bacteria is one of the main problems for seafood safety. They do not cause any evident change in the appearance of seafood, but they may cause foodborne illnesses ranging from nausea and vomiting to death. Since it is impossible to recognize pathogen existence in seafood by its appearance, consuming contaminated seafood poses a significant risk for human health (Brown et al., 2011). Pathogenic bacteria pose a significant risk for the consumer, especially when raw or insufficiently cooked seafood is consumed. Anthropogenic effects change ecological processes and convert naturally occurring pathogens to human health risks.

Secondary contamination is a critical issue for seafood. Seafood may become contaminated due to improper handling and processing conditions, and even they were caught from clean waters. For instance, Clostridium botulinum type $\mathrm{E}$ usually is not present in fresh fish caught from unpolluted areas. However, it is one of the main problems for the seafood industry since it may grow and produce toxin due to defective handling and processing (Sikorski et al., 1990). Since most food poisoning episodes are related to Salmonellosis, contamination of seafood with Salmonella is a critical food safety issue. Likewise, smoked seafood processing plants must be strictly controlled to prevent Listeria contamination. Seafood is suitable for bacterial growth due to its high post-mortem $\mathrm{pH}$, high moisture content, and appreciable amounts of non-protein nitrogen (Lampila and McMillin, 2012).

The indigenous pathogens for fish and seafood are psychrotrophic non-proteolytic C. botulinum types B, E, and $F$, psychrotolerant histamine-producing bacteria, Listeria monocytogenes, Vibrio cholerae, Vibrio parahaemolyticus, Vibrio vulnificus, Aeromonas hydrophila, and Plesiomonas shigelloides. On the other side, Staphylococcus aureus, $C$. botulinum proteolytic type $A$ and $B$, mesophilic histamine-producing bacteria, Salmonella spp., Shigella spp. and Escherichia coli are the non-indigenous bacteria that contaminate fish and seafood. Salmonella spp., Shigella spp., and E. coli may be found on seafood due to fecal contamination.

\section{Clostridium botulinum}

Clostridium botulinum is a Gram-positive, sporeforming, anaerobic, and catalase-negative rod-shaped bacterium that produces a neurotoxic protein known as botulinum neurotoxin (Botulin). Botulin is a rare toxin but threatens human life. C. botulinum species are divided into seven types ( $A$ to $G$ ) based on the serology of the toxins produced. Non-proteolytic type $E$ is the most common one in seafood. It is widely assumed that 
C. botulinum spores are more common in aquatic foods than other foods. (Lampila and McMillin, 2012). An outbreak of $C$. botulinum types A, B, and $E$ was reported in China due to consuming vacuum-packaged salted fish and ham. Four patients were reported with gastrointestinal symptoms, vomiting and one of them died. Early diagnosis, especially the treatment of illnesses related to botulism type $E$, was emphasized due to the risk of respiratory failure (Min et al., 2021). Rasetti-Escargueil et al. (2020) expressed fish as a carrier of $C$. botulinum $E$ and stated that fish might pose a widespread risk of botulism transmission to humans. When botulism risk is mentioned, especially canned fish has been considered. The frequency of foodborne botulism outbreaks in patients referred to a hospital in Iran between 2008 - 2019 was examined. It was determined that canned fish consumption is an important cause of botulism (Dallal et al., 2020). Semenko et al. (2021) studied the foodborne botulism cases in Ukraine between 1955 - 2018 and defined homemade canned meat and fish as the leading causes of botulism.

The conditions required for foodborne botulism are contamination with $C$. botulinum, surviving spores during processing, a suitable environment for growth and toxin production, and finally, consuming food without sufficient heating. A very small amount of toxin measured in nanograms may cause botulism poisoning. In other words, $0.1 \mathrm{~g}$ of food containing the botulin toxin may lead to botulism (Armstrong, 2004). Whenever the environmental conditions are favorable for the growth and toxin production of the pathogen, there will be a potential risk for botulism. The toxin can be formed in the product without any noticeable change in the sensory properties of fish. So, the consumer may not feel abnormal flavors or odors and may eat fish containing the toxin. The proteolytic $C$. botulinum strains have relatively higher heat resistance. However, the psychrotrophic, non-proteolytic strains of $C$. botulinum have been given more attention than the proteolytic strains. Because they may grow at temperatures as low as $3^{\circ} \mathrm{C}$ in contrast to proteolytic strains that cannot grow below $10^{\circ} \mathrm{C}$. Clostridium botulinum type $\mathrm{E}$ could be a risk for vacuum and modified atmosphere-packed seafood since it is an aquatic microorganism and capable of growth at $3-4^{\circ} \mathrm{C}$ under anaerobic conditions. Fish are cold-blooded animals and the natural microbiota is often adapted to low temperatures. So, $C$. botulinum is not considered a risk; however, keeping fish below $3^{\circ} \mathrm{C}$ is recommended to prevent its growth and toxin formation under anaerobic conditions (ICMSF, 2011). Minor temperature abuses can dramatically affect toxin production. The spores of non-proteolytic $C$. botulinum are not inactivated by pasteurization; therefore, the fish should be stored below $3.3^{\circ} \mathrm{C}$ for less than four weeks (Baldwin, 2012). On the other hand, rapid chilling is recommended to prevent possible germination of surviving $C$. botulinum spores, although the chilling rate can vary depending on pack size and chilling method.

\section{Listeria monocytogenes}

Listeria monocytogenes is a Gram-positive and non-sporeforming rod-shaped bacterium. As a psychrotrophic pathogen, L. monocytogenes can grow at low temperatures just above $0^{\circ} \mathrm{C}$. It can grow under aerobic, anaerobic, or microaerophilic conditions. Listeria monocytogenes may cause listeriosis, leading to high mortality rates, especially in high-risk groups. In recent years, the incidence of listeriosis has increased in Europe, so studies on the presence of L. monocytogenes in foods have gained importance. The contamination of machines and staff movement in processing areas have been reported to be the most important causes of the presence of this pathogen in a ready-to-eat fish processing facility. The occurrence of this pathogen in seafood processing facilities is an important issue, and periodical cleaning procedures are recommended to be applied regularly to prevent contamination (AaltoAraneda et al., 2019). Smoked fish is a potential vehicle for $L$. monocytogenes since the smoking process contains various opportunities for contamination or recontamination. The other possible reasons are the increased storage life of smoked fish, contamination of the raw material, contamination after processing, the ability of packaging to support L. monocytogenes growth.

Survey studies have revealed that the contamination of fish and other foods with $L$. monocytogenes is quite common, although the contamination levels show variations. This pathogen is a significant problem for the smoked seafood industry and can be found on raw fish, smoked products, or work surfaces in a smoking facility. Listeria monocytogenes can be isolated from marine and freshwater species. The risk assessment on L. monocytogenes showed that $7 \%$ of raw fish are contaminated with this pathogen 1-1000 cfu/g, while approximately $92 \%$ are contaminated less than $1 \mathrm{cfu} / \mathrm{g}$ (Rosnes et al., 2011).

\section{Salmonella sp.}

Salmonellae are Gram-negative bacilli belonging to Enterobacteriaceae, and many serovars have been identified. They are mainly present in the gut of humans and animals and environments polluted with feces. Contamination of fish and other seafood with Salmonella is a significant risk due to the increased pollution of waters and poor hygienic conditions after the catch. Frogs caught from polluted waters may be contaminated with Salmonella (Costa et al., 2021). Salmonella has been reported as the reason for $12 \%$ of the outbreaks related to seafood consumption (Huss et al., 2000). Mol et al. (2010) studied the effect of salting and drying processes on Salmonella Enteritidis, inoculated on horse mackerel. They reported that these techniques may reduce aw, sufficient to inhibit this 
pathogen, depending on processing periods. Salmonella enterica was reported to be survived in frozen seafood at the level of 8 log cfu/g for 90 days (Don et al., 2020). This pathogen poses a significant risk, either for fresh or processed seafood.

\section{Clostridium perfringens}

Clostridium perfringens is an anaerobic, Grampositive, non-motile, and spore-forming rod-shaped bacterium, common in nature, mainly in soil. It was also isolated from water and sediments, the gut of cod, and different freshwater fishes (Lunestad et al., 2011). C. perfringens grows in the absence of oxygen and forms a heat-resistant spore. The spores can germinate and outgrow if the product is inadequately cooled, stored, or reheated. The optimal growth occurs at $43-45^{\circ} \mathrm{C}$, while the minimum and maximum temperatures needed for growth are $15^{\circ} \mathrm{C}$ and $50^{\circ} \mathrm{C}$. The food poisoning caused by $C$. perfringens occurs after ingestion of viable vegetative cells of the organism, and the low $\mathrm{pH}$ of the stomach may stimulate the sporulation. Then enterotoxin is released, and result in disease in humans. The high resistance of $C$. perfringens fish isolates to antibiotics has been regarded as an alarming sign since human illnesses caused by this pathogen are commonly treated with antibiotics (Hafeez et al., 2021). The studies on the incidence of $C$. perfringens reveal that this pathogen may be found in fish and seafood products. Anihouvi (2020) studied the microbiological quality of smoked and smoked-dried fish and reported no $C$. perfringens growth after implementing improved processing practices. Therefore, they highlighted the importance and effect of good manufacturing practices in the fish processing industry to enhance safety. $C$. perfringens generally cannot grow at low temperatures. The minimum growth temperature is $12^{\circ} \mathrm{C}$, and its growth rate slows below $20^{\circ} \mathrm{C}$. Therefore, controlled chilled storage can prevent $C$. perfringens risk.

\section{Bacillus cereus}

Bacillus species are facultative anaerobic, Grampositive, spore-forming, and rod-shaped bacteria widely distributed in nature. They are primarily of plant origin but may also be found in fish products. The most important pathogenic species related to food is Bacillus cereus, which may cause different poisonings, including emetic disease and diarrhea. Most strains are mesophilic with an optimum growth temperature of 30$40^{\circ} \mathrm{C}$. Bacillus species may be found in complex fish products, including vegetables, spices, rice, milk, and flour. However, the emetic disease caused by $B$. cereus after consuming cooked tuna fish was reported by Doménech-Sánchez et al. (2011). Authors have stated that it was the first case of emetic disease $B$. cereus likely to be associated with fish consumption. Enterotoxinproducing $B$. cereus has been isolated from fresh and processed seafood. A high prevalence of $B$. cereus has been reported in shellfish cultivated in brackish waters around Taiwan, and new enterotoxin gene profiles were reported in their habitats (Hsu et al., 2021).

\section{Staphylococcus aureus}

Staphylococcus aureus is a non-motile, facultative anaerobic, mesophilic, and Gram-positive sphereshaped bacterium. Its presence is associated chiefly with post-processing contamination. Higher numbers of $S$. aureus can be found in processed seafood than in fresh ones. This pathogen may grow and produce toxins in cooked and peeled crustaceans or smoked fish that are poorly handled during processing. Since processing and transportation may lead to the transfer of $S$. aureus, providing good hygienic practices is essential, especially in the retail markets (Lampila and McMillin, 2012).

\section{Vibrio parahaemolyticus}

Vibrio species are primarily found in molluscan shellfish, harvested from unapproved areas. The water quality directly impacts the safety of mollusks since they concentrate microorganisms and toxic substances from polluted water. On the other hand, the habitats where molluscan shellfish grow are generally subject to pollution. The habit of consuming raw or undercooked mollusks is the other significant risk factor. The potential risks regarding molluscan shellfish safety increase during spring and summer due to the increasing water temperatures. Since bivalves are filter feeders, they may concentrate high numbers of Vibrio parahaemolyticus. This bacterium may also be found in shrimp and crab from warm coastal waters, and it may be destroyed by adequate cooking. Vibrio parahaemolyticus has been reported to be the primary pathogen causing gastroenteritis in Korea (Jo et al., 2020). The occurrence of this pathogen is dependent on seasons and high in summer. Regular monitoring is essential to control seafood-borne outbreaks due to V. parahaemolyticus. Su and Chen (2020) reported extremely low occurrence of pathogenic $V$. parahaemolyticus but high percentages of antimicrobial resistance in commonly consumed seafood in China. Therefore, they emphasized the imperative need to risk assessment of seafood regarding food safety.

The other species of Vibrio, such as $V$. vulnificus, $V$. cholera $\mathrm{O} 1$, and $V$. cholera non-O1, are naturally found in warm coastal waters. Mainly bivalve shellfish processing establishments must be effectively controlled as to this pathogen.

\section{Escherichia coli}

Escherichia coli is an indicator of fecal contamination, and it may transfer fish via the contaminated aquatic environment (Cardozo et al., 2018). Many serotypes of $E$. coli are reported as toxinproducers. The pathogenic serotypes of intestinal $E$. coli 
may cause diseases in the urinary or central nervous systems and the gastrointestinal tract.

Escherichia coli serotype 0157:H7 was identified as a pathogen in 1982 due to its association with foodrelated outbreaks (Turgut, 2021). Today, it is recognized as a significant cause of foodborne disease and a potential threat to public health (Ayodele et al., 2020). Fish can be a vehicle for transferring this bacterium to the consumer, although it is not the primary source (Onmaz et al., 2020). Proper sanitary practices during processing and sufficient cooking of animal-origin foods are essential to control E. coli 0157:H7 infections. The consumption of raw or undercooked fish may lead to infections. Especially in developed or underdeveloped countries, job training about proper fish handling practices may help reduce the contamination level of fish (Assefa et al., 2019). E. coli 0157:H7 produces enterohemorrhagic toxins and other virulence factors. It may cause bloody and painful diarrhea and can lead to severe complications. Post-processing contamination is the other reason for outbreaks due to this pathogen.

\section{Aeromonas hydrophila}

Aeromonas hydrophila was determined as the predominant organism in freshwater fish (38\%), shellfish (78-86\%), and marine finfish (93\%). The genus Aeromonas consists of Gram-negative rods commonly found in aquatic environments. The species of this genus have attracted increased attention because of their ability to grow at low temperatures. Since A. hydrophila has a broad growth temperature range, it may multiply on fish during storage, transport, marketing, or keeping in domestic refrigerators. Therefore, fish has been regarded as the major transmitter of this pathogen to humans. Good hygienic practices are essential to prevent contamination (Pal, 2018).

\section{Viruses}

The contamination of food with viruses is an important issue since foodborne viruses are usually resistant to processing or preservation methods such as acid, heat, drying, pressure, disinfectants, UV, or radiation. Although viruses are among the factors that cause the most foodborne diseases, there is no systematic monitoring of legislation to control virus incidence in foods. In order to prevent virus contamination, it is essential to ensure control by making legal arrangements and training food industry employees and managers about hygiene.

Norovirus (NoV), hepatitis A virus (HAV), hepatitis E virus (HEV), and rotavirus are listed as primary hazards as a food-related viral threat (FAO/WHO, 2008). The incidence of these viruses was studied in fish and shrimp from the Persian Gulf. It was reported that the level of contamination significantly varied depending on the season and the species (Amroabadi et al., 2021).
Norovirus (NoV): Noroviruses are also called "Norwalk virus" or "Norwalk-like virus", which may lead to epidemics of acute gastrointestinal disease. The symptoms primarily seen in humans are nausea, vomiting, diarrhea, and stomach pain due to acute gastroenteritis. Filter-feeder shellfish are incriminated foods because they may concentrate various microorganisms, including viruses, on their gills. Therefore, it is advised to increase good hygienic practices for food handlers and cook shellfish sufficiently before eating (Velebit et al., 2019). Das et al. (2020) reported a high incidence of NoV on seafood (41.34\%) exposed to fecal contamination. They found the highest NoV in bivalves (52.7\%), fish (16.7\%), and crustaceans (11\%) and stated that the presence of high amounts of $\mathrm{NoV}$ in seafood indicates widespread anthropogenic contamination of the environment. NoV, common both in the developing and developed countries, is the cause of almost half of all foodborne illness outbreaks in the US (Brunette, 2017). Regulatory authorities are focusing on establishing an infectious dose for various foods, including shellfish, on reducing the risk of Norovirus, and new methods have been developed to detect viruses such as NoV in food (Hennechart-Collette et al., 2021). Novel techniques such as atmospheric pressure plasma jet reported being effective inactivating norovirus on salmon sashimi (Huang et al., 2021).

Hepatitis E virüs (HEV): HEV is not very common in industrialized countries but may be the main reason for outbreaks in tropical and subtropical countries. Shellfish in tropical regions are risk factors for HEV transmission. Under-cooked or raw shellfish have been indicated as food commodities with the risk of HEV infection (Velebit et al., 2019). Pavio et al. (2021) also associated HEV exposure with shellfish consumption.Fecalcontaminated water is the leading transmission route, and HEV has been recognized as the main reason for viral hepatitis, especially in developing countries. The mortality risk is high in pregnant women, and the illness is generally severe (FAO/WHO, 2008). Since bivalve shellfish filter water during feeding, the virus concentration in their edible tissues may be much higher than in their surrounding waters.

Hepatitis A virus (HAV): The presence of hepatitis A virus (HAV) is mainly associated with the sewage contamination of foods and poor hygienic conditions of food handlers and farmers. Since good hygienic practices and sanitation can significantly reduce HAV transmission, its prevalence is lower than NoVs. Even though handling by infected workers may also result in contamination of $\mathrm{NoV}$ and $\mathrm{HAV}$; the main route of transmitting is the harvesting of shellfish from fecalcontaminated areas (FAO/WHO, 2008). Bivalves such as mussels, oysters, or clams filter off their food from the water, and they may be contaminated with this virus. The first HAV outbreak was reported in 1955 and affected 629 people due to the consumption of raw oysters. Then, in 1988, almost 300000 people were 
infected HAV due to eating clams collected from a sewage-polluted area. This outbreak has been reported as the most significant (Price, 1999). The current microbiological guidelines mainly target bacteriological analyses and mostly fail to determine the presence of viruses. Dirks et al. (2021) emphasized the necessity of monitoring NoV and HAV levels in bivalve mollusks for critical risk assessment and management. The potential of depurated shellfish to carry viral risks should not be overlooked. The minimum infective dose is unknown, but this is probably a figure for less than 100 viruses (Velebit et al., 2019). Di Cola et al. (2021) stated that there is still very little data on the prevalence, sources, and frequency of HAV and HEV contamination. They emphasized the need for a standard methodology for HEV detection in foods.

Adenovirus: Adenoviruses have been isolated from wastewater, seawater, and shellfish. They are widely found in the environment and, when infecting humans, may cause gastroenteritis and conjunctivitis. Even the symptoms are not very strong; a large amount of the virus is shed in feces and respiratory secretions for months or years after infection. Myrmel et al. (2004) detected Adenoviroses in $18.6 \%$ of samples, including finfish and bivalve mollusks from Norwegian coasts, and emphasized routine testing of samples regarding the risk of virus infection. Similarly, adenovirus was detected in $46.15 \%$ of mussels from Turkish waters (Ghalyoun and Alcay, 2018).

Astrovirus: Astrovirus transmission may result in diarrhea, fever, nausea, weakness, and vomiting in humans. Shellfish are among the contaminated foods with astrovirus during the pre-harvest, and children's acute diarrhea is significantly related to this virus. Although diarrhea usually does not last more than 2-3 days, it can last up to 14 days with the scattering of the virus in the stool. Viral contamination levels could vary depending on the seasons, and sometimes $50 \%$ of shellfish, such as mussels, may be contaminated with this virus. Astrovirus usually causes milder symptoms than rotavirus. Astrovirus was reported in $63.46 \%$ of the mussels collected from Turkish fish markets (Ghalyoun and Alcay, 2018).

\section{Heavy Metals}

Pollutant levels are increasing in the environment as a negative result of anthropogenic activities, and heavy metals are the primary pollutants in water resources. Although many trace elements are essential biological substances, some are potentially toxic and can be very harmful to human health even in minimal quantities. These may accumulate in fish and shellfish and transfer to humans through the food chain. Demersal species, bivalve mollusks, and long-lived predator fish such as tuna, swordfish, or sharks are known for their potential to concentrate metals in their tissues due to their biological features and habitats.
Mercury $(\mathrm{Hg})$ is a well-known toxic trace element that threatens human health, and it is one of the severe pollutants. Methylmercury is the main source of organic $\mathrm{Hg}$ formed from the inorganic $\mathrm{Hg}$ in the aquatic environment. Exposure may result in adverse health effects on the brain and nervous system over time and may increase the risk of coronary heart disease (US EPA, 2017). It may cause behavioral disorders in children and may damage fetus during pregnancy. Fortunately, selenium (Se), another element found in fish, can detoxify $\mathrm{Hg}$ and reduce $\mathrm{Hg}$ accumulation in mammals and fish. Selenoprotein is an essential compound of Se, and it reduces the toxic effect of $\mathrm{Hg}$. So, it has been advised to assess the molar ratio of $\mathrm{Hg}$ :Se to clarify the effects of $\mathrm{Hg}$ exposure. Indeed, the risk from mercury exposure from various fish species was evaluated considering the interactions between selenium and mercury, and no health risk was reported due to the protective effect of Se on $\mathrm{Hg}$. It was stated that the fish could be safely consumed when the $\mathrm{Se} / \mathrm{Hg}$ ratio was above one, and the Se-HBV was positive (Ralston et al., 2008). For this reason, it was emphasized that it is vital to monitor Se level as well as $\mathrm{Hg}$ (Ulusoy et al., 2019). Selenium can also prevent human form diseases, and low to medium Se intake is advised to support a healthy life. Excessive Se intake may have adverse health effects. Still, most Europeans have some health problems due to its deficiency in the diet since they take this element generally below the recommended amount (Ježek et al., 2012).

Cadmium (Cd) is also a human carcinogen with adverse health effects on the kidney, skeletal, and respiratory systems. Fish has been regarded as the primary source of cadmium exposure for humans. Other elements that may threaten human health due to fish consumption are Lead (Pb) and Arsenic (As). The nervous system, kidney, hematological, and cardiovascular systems may be injured when high concentrations of $\mathrm{Pb}$ are taken by diet regularly. Arsenic is a highly toxic element, but thankfully most of it (about $98 \%$ ) is found as the nontoxic organic form in fish flesh (EFSA, 2009). Cooper ( $\mathrm{Cu}$ ) and zinc (Zn) are essential elements and are needed for the metabolic activities of the human body. However, they may cause illnesses such as liver and kidney damage when elevated concentrations are digested. Therefore, their concentrations are also monitored in fish and shellfish (Ashraf et al., 2006).

Various national and international guidelines specify the permitted maximum amounts of toxic elements present in fish or shellfish. The safety of the fish is evaluated by monitoring whether the trace element concentrations detected in edible muscles exceed this level. However, due to their eating habits, the fish consumption amounts may vary significantly in different countries. So, the risk of heavy metals from eating fish is not the same for every society, and consumption amounts should also be considered when assessing health risks for different populations. 
Potential heavy metals risks due to consuming thornback ray and spiny dogfish were evaluated for Turkish and Greek people by Mol et al. (2019). The differences in the potential health risks of these two communities resulted from their fish consumption rates.

\section{OCPs, PCBs and BFRs}

Increasing agricultural activities lead to pollution of the environment with organic and inorganic pollutants. As well as the local emission, long-distance atmospheric transportation is also reported to be an essential factor concerning the accumulation of contaminants (Riaz et al., 2021). Dichlorodiphenyltrichloroethane (DDT), hexachlorocyclohexane $(\mathrm{HCH})$, endrin, and aldrin are the most used OCPs. Synthetic organic chemicals are the other important pollutants used in industrial applications and enter into waters and transfer to humans due to the food chain. They are commonly termed Polychlorinated biphenyls (PCBs). Likewise, in a recent study, PCBs and OCPs reported posing potential carcinogenic and non-carcinogenic risks and the need of implementing emission standards for pollutants indicated (Chen et al., 2021). On the other hand, OCPs and PCBs in Pacific salmon were reported to decrease from 2012 to 2018, showing their elimination from the Northwest Pacific (Donets et al., 2021).

Brominated flame retardants (BFRs) are other pollutants that have been mentioned to accumulate in fish. They are widely used to prevent unwanted ignition of various products. BFRs are synthetic chemicals and have bioaccumulative, persistent, and toxic effects when released into the environment. Hexabromocyclododecanes (HBCDs), polybrominated diphenyl ethers (PBDEs), and tetrabromobisphenol-A (TBBP-A) are the widely used BFRs and restricted due to their high ecological and health risks (Tao et al., 2019). Habitat, season, trophic level, and rainfalls are reported to be factors influencing the formation of OCPS, PCPS, and BFRs, and seasonal effects may increase pollution in the tropic regions (Haarr et al., 2021).

\section{Microplastics}

Plastics are produced in large quantities for various purposes and dissolve very slowly. Their complete decomposition takes centuries, even millennia. Therefore, plastic particles accumulate in the environment and threaten animal and human life. Microplastics $(<5 \mathrm{~mm}$ ) are widely present in the aquatic environment due to anthropogenic activities, and aquatic organisms may ingest these particles. When the fish samples from a museum were examined, very few microplastics were reported in 20th-century fish (Toner et al., 2021). But today, the presence of microplastics has been reported in 323 fish species, $81 \%$ of which are of commercial value, and has become an important issue for human health and food safety (Markic et al.,
2020). Recent scientific studies report the adverse effects of microplastics on the environment, aquatic animals, and transfer to humans via the food chain (Ghosh et al., 2021; Cabansag et al., 2021; Rasta et al., 2021; Parvin et al., 2021). It is foreseen that contamination of fish with microplastics will be a rising problem awaiting a solution.

Microfibers (MFs) have been considered the primary sources of aquatic microplastic pollution. Lethal effects of microfibers have been reported in marine animals and terrestrial organisms, and domestic washing has been stated as their primary source (Singh et al., 2020).

\section{Recent Potential Threats via Seafood}

\section{Effects of Climate Change on Seafood}

Climate change is one of the biggest global problems of today. It may threaten the reliability, diversity, quantity, and quality of fishery products. As a result of global warming, water level, salinity, and dissolved oxygen amounts change while pathogens and toxic algae spread globally (Lotze et al., 2021). Rising seawater temperature may affect the distribution of many fish species, cause mutations, reduce survival rate, or reduce species diversity. Therefore, climate change may adversely affect aquaculture, fisheries, seafood trade, and fish processing sectors. These effects may have economic, social, and environmental consequences as well as public health effects.

Depending on climate change, it is expected that the amount of pollutants in the waters will increase due to the expanded amount of soil transfer to the water (Kibria et al., 2021). Increased temperature and acid rains raise heavy metal concentration in the water. Thus, aquatic organisms concentrate higher amounts of heavy metals in their tissues. The temperature has been known as a critical factor affecting the metal uptake of aquatic organisms. Warming waters will facilitate mercury methylation and increase the methylmercury uptake in fish by about 3-5\% when the temperature rises by $1^{\circ} \mathrm{C}$. The interactive effects of climate change and increased concentrations of pollutants result in the toxicity/lethality of seafood, threatening their survival (Kibria et al., 2021). Transmission of contaminants from the environment is a crucial threat to fish survival and consumer health.

As a result of climate change, the annual temporary period of harmful algal blooms that occur may also be extended (Tirado et al., 2010). Climate change will lead to an increase in toxic algae in waters, and as a result, the frequency, severity, and number of areas where shellfish poisoning will increase. There is a possibility that climate changes will create a marine environment to which harmful algae adapt. Harmful algal blooms have become more frequent, intense, and common in recent years. The biggest concern about toxin-producing algae is the poisoning caused by the 
consumption of shellfish and fish, which can be fatal. Shellfish poisoning outbreaks are predicted to be more frequent due to the future climate scenario. As a result of global climate change, hazardous algae lead to the formation of Paralytic (PSP), Amnesic (APS), Diarrhetic (DSP), Neurotoxic (NSP), and Azaspiracid (AZP) Shellfish Poisonings, and negatively affect human health. As well as shellfish poisonings, ciguatera also caused by algae blooms may also pose public health risks in some regions. In 1990, 3-7.5\% of people from the South Pacific were exposed to Ciguatera poisoning. This number is predicted to be $16-43 \%$ by 2050 due to increased temperature. Besides, it has been expected to spread ciguatera poisoning to higher altitudes due to the increased number of toxic phytoplankton, Gamberdiscus toxicus following increased temperature (Llewellyn, 2010).

An increase in temperature and changes in precipitation patterns will increase the resistance and incidence of bacteria, viruses, parasites, and fungi, which will cause rises in foodborne diseases. The transmission cycle of parasites has been affected by climate change. When the temperature is high, within the temperature range of the host and the parasite, the cercariae output almost doubles. Therefore, a slight rise in water temperature expands the geological distribution of nematodes and increases their proliferation in the infective stages in many ecosystems. The probability of enteric virus contamination in waters also increases due to climate change. Because flood events rise globally and untreated sewage water may overflow and contaminate clean waters.

Another significant problem caused by climate change is the increased load of pathogenic bacteria in waters and aquatic organisms. It is known that the number of pathogens causing gastroenteritis, such as Clostridium, Vibrio, Aeromonas spp., significantly increase in summer seasons. So, it is predicted that the increased temperature due to climate change will spread worldwide in the future. The rapid spread of a new serotype of Vibrio parahaemolyticus (03:K6) caused a worldwide epidemic in recent years. This finding indicates that new public health risks may be encountered (Tirado et al., 2010). In addition to increasing temperature, changes in factors such as sea level, precipitation, flood, and salinity also affect the microflora of the water, and pathogens carried by ballast waters can spread easily. Shellfish are expected to be the main pathogen transmission route to humans, as they are filter-feeders and are generally consumed raw.

Acidification is the other adverse effect of climate change on water resources. Acidification of water is the phenomenon of declining $\mathrm{pH}$ in water sources due to the absorbed atmospheric carbon dioxide by the water. On the other hand, reduced calcification of most corals has been reported. The future presence of coral reefs is a great concern since they create a unique ecosystem and provide a habitat for many commercial species. Crustaceans may not form shells due to the reduction of calcification, and the availability of these foods on our tables will come to an end. Acidification may also result in a higher accumulation of pollutants in seafood (Kibria et al., 2021).

Climate change will make our seafood insufficient in terms of quantity and safety due to the negative impacts such as increased levels of pollutants, parasites, viruses, pathogens, acidification, and toxicities such as

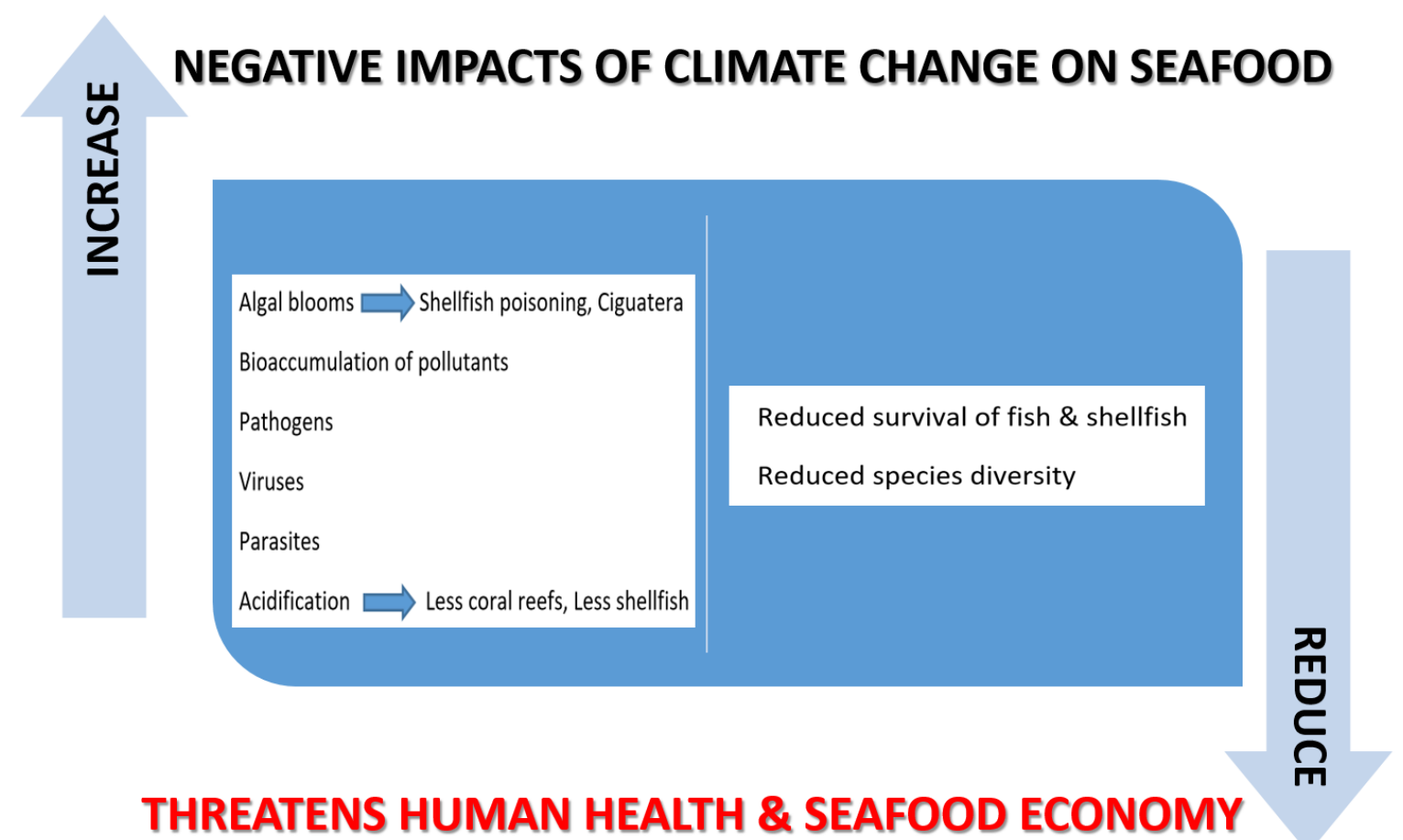

Figure 2. Negative impacts of climate change on seafood 
shellfish poisoning and Ciguatera (Figure 2). Food safety programs should be created globally to decrease greenhouse gas emissions and support eco-friendly technologies. Strategies need to be developed to tackle new challenges such as climate change affecting seafood quality and microbial safety. New strategies will help maintain the safety and quality of seafood from farm to fork to address One Health and Sustainable Development Goals.

\section{Antibiotic Resistance}

The transfer of antibiotic resistance genes through food poses a significant threat to public health. The promoted growth in agriculture and the widespread use of antibiotics raise concerns for food safety. The antibiotic residues transfer between the animals, environment, and humans. So, antibiotic resistance occurs, depending on the transmitted antibiotic amount. Excessive industrialized practices and high demand for food have led to severe bacterial diseases in agriculture, animal husbandry, and aquaculture. So, the use of antibiotics has increased. Antibiotics used to cure human and terrestrial animals transfer into the soil and water, leading to increased resistance in pathogens.

Moreover, according to a recent report, using one type of antibiotic /antimicrobial may result in crossresistance to others (Sony et al., 2021). Antibiotic residues support the proliferation of antibiotic resistance genes. Antibiotics resistance genes and antibiotics alter microbial communities and biogeochemical cycles and threat marine organisms and human health (Wang et al., 2022).

Antibiotic resistance has also been reported in fish through their diet and aquatic habitat. Antibiotic resistance to pathogenic Vibrio spp. is reported to be highly prevalent in marine fish from South China (Deng et al., 2020). A study in South Korea indicated that farmed fish contain higher amounts of opportunistic pathogens than wild fish, and fish farms may be a source for antibiotic resistance gene dissemination. The necessity of monitoring antibiotic resistance genes in fish farms and the need for actions have been emphasized (Jo et al., 2021).

Algammal et al. (2022) studied the antimicrobial resistance of emerging multi-drug resistant Edwardsiella tarda in fish and reported a significant correlation between phenotypic antimicrobial susceptibility, virulence determinants, and inherited resistance genes. Today, pathogens continuously contact antibiotic or antimicrobial wastes, becoming resistant to these substances. Medical treatment possibilities are limited when humans are infected with antimicrobial/antibiotic-resistant pathogens. That is to say, if the causative pathogen has antimicrobial resistance genes, recovery of the patient will be difficult or will not be possible. Due to antibiotic resistance, the cure of infections getting harder in recent years. As well as increasing mortality, antibiotic resistance increases the medical cost due to the increased length of hospital stay. Therefore, antimicrobial resistance is a serious problem of this century. WHO (2021) recommends raising awareness of antimicrobial resistance, optimizing the use of antibiotics, strengthening research and surveillance, reducing the incidence of infection, and maintaining investment to combat antimicrobial resistance to reduce antimicrobial resistance.

\section{Conclusion}

Fish and other seafood are the most sensitive foods to spoilage, and they may contain some food safety risks for the consumer. Receiving seafood from an approved vendor, obtaining a fisheries certificate of origin, preventing secondary contamination after catch or harvest, ensuring an unbroken cold chain, applying sufficient time and temperature for heat-treated products are the most critical factors in preventing potential hazards and delaying spoilage. International engagements should bring long-term solutions to global problems such as antibiotic resistance and climate change. Implementation of these practices will provide remarkable benefits in terms of food safety and the economy.

\section{Ethical Statement}

Not applicable.

\section{Funding Information}

Not funded.

\section{Author Contribution}

First Author: Conceptualization, Writing -review and editing.

\section{Conflict of Interest}

The author(s) declare that they have no known competing financial or non-financial, professional, or personal conflicts that could have appeared to influence the work reported in this paper.

\section{Acknowledgements}

Both authors contributed equally to this work.

\section{References}

Aalto-Araneda, M., Lundén, J., \& Markkula, A. (2019). Processing plant and machinery sanitation and hygiene practices associate with Listeria monocytogenes occurrence in ready-to-eat fish products. Food Microbiology, 82, 455-464.

Abraham, A., Flewelling, L.J., \& El Said, K.R. (2021). An occurrence of neurotoxic shellfish poisoning by consumption of gastropods contaminated with brevetoxins. Toxicon, 191, 9-17. 
Akbora, H.D., Kunter, I., \& Ercetin, T. (2020). Determination of tetrodotoxin (TTX) levels in various tissues of the silver cheeked puffer fish (Lagocephalus sceleratus (Gmelin, 1789)) in Northern Cyprus Sea (Eastern Mediterranean). Toxicon, 175, 1-6.

Algammal, A.M., Mabrok, M., Ezzat, M., Alfifi, K.J., Esawy, A.M., Elmasry, N., El-Tarabili, R.M (2022). Prevalence, antimicrobial resistance (AMR) pattern, virulence determinant and AMR genes of emerging multi-drug resistant Edwardsiella tarda in Nile tilapia and African catfish, Aquaculture, 548 (1), 737643.

Almeida, L.K., Gushken, F., Abregu-Diaz, D.R., Muniz, R., \& Degani-Costa, L.H. (2019). Rhabdomyolysis following fish consumption: a contained outbreak of Haff Disease in São Paulo. Brazilian Journal of Infectious Diseases, 23, 278-280.

Ameen, I., Hidan, M., Mostefaoui, Z. \& Ali, H.M. (2020) Fractional Optimal Control with Fish Consumption to Prevent the Risk of Coronary Heart Disease, Complexity, 13.

Amroabadi, M.A., Rahimi, E., \& Shakerian, A. (2021). Incidence of hepatitis $A$ and hepatitis $E$ viruses and norovirus and rotavirus in fish and shrimp samples caught from the Persian Gulf. Arquivo Brasileiro de Medicina Veterinária e Zootecnia, 73 (1),169-178.

Anderson, D.M., Fensin, E., \& Gobler, C.J. (2021). Marine harmful algal blooms (HABs) in the United States: History, current status and future trends. Harmful Algae, 102, 101975.

Annunziata, L., Schirone, M., Campana, G., De Massis, M.R., Scortichini, G., \& Visciano, P. (2022). Histamine in fish and fish products: An 8-year survey. Follow up and official control activities in the Abruzzo region (Central Italy). Food Control, 133, 108651.

Armstrong, G.A. (2004) Minimal thermal processing: cook-chill and sous vide technology. In: Y.H. Hui, S. Ghazala, D.M., Graham, K.D. Murrel, \& W.K., Nip (eds.) Handbook of Vegetable Preservation and Processing. Marcel Dekker Inc, NY, USA, p 409-423.

Ashraf, W., Seddigi, Z., Abulkiibash, A. \& Khalid, M. (2006). Levels of selected metals in canned fish consumed in Kingdom of Saudi Arabia. Environmental Monitoring and Assessment. 117, 271-279.

Assefa, A., Regassa, F., \& Ayana, D. (2019). Prevalence and antibiotic susceptibility pattern of Escherichia coli 0157:H7 isolated from harvested fish at Lake Hayq and Tekeze dam, Northern Ethiopia. Heliyon. 10, 5(12):e02996.

Anihouvi, D.G.H. (2020). Microbiological quality of grilled pork, smoked and smoked-dried fish in Benin: problems and improvements, Thesis, J. Mahillon, V. Anihouvi, (Promotors)

https://dial.uclouvain.be/pr/boreal/object/boreal:2406 28.

Ayodele, O.A., Deji-Agboola, A.M., \& Faneye, A.O. (2020). Characterization and Antibiotic Susceptibility of E. Coli O157:H7 in Meat and Fish Sold in Major Ibadan Markets, Nigeria. American Journal of Biomedical Sciences, 12(2), 99-106.

Bairagi, S., Mohanty, S., Baruah, S. \& Thi, H.T. (2020). Changing food consumption patterns in rural and urban Vietnam: Implications for a future food supply system. Australian Journal of Agricultural and Resource Economics, 64, 750775.

Baldwin, D.E. (2012). Sous vide cooking: A review.
International Journal of Gastronomy and Food Science, 1 15-30.

Belizario, V.Y., Totañes, F.I.G. (2014). Helminth - nematode: Capillaria hepatica and Capillaria philippinensis. Encyclopedia of Food Safety, 2, 90-93.

Biessy, L., Boundy, M.J., \& Smith, K.F. (2019). Tetrodotoxin in marine bivalves and edible gastropods: A mini-review. Chemosphere, 236, 124404.

Bordin, P., Dall'Ara, S., \& Tartaglione, L. (2021). First occurrence of tetrodotoxins in bivalve mollusks from Northern Adriatic Sea (Italy). Food Control, 120, 107510.

Bresnan, E., Arévalo, F., \& Belin, C. (2021). Diversity and regional distribution of harmful algal events along the Atlantic margin of Europe. Harmful Algae, 102,101976.

Brown, H., Williams, J., \& Kirwan, M. (2011). Packaged product quality and shelf life. In. R. Coles, \& M. Kirwan (Ed.), Food and beverage packaging technology. (pp. 59-84). WileyBlackwell, UK.

Brunette, G.W. (2017). CDC Yellow Book 2018: Health Information for International Travel. Oxford University Press. p. 269. ISBN 9780190628611.

Cabansag, C.B.P., Olimberio, R.B., \& Villanobos, Z.M.T. (2021). Microplastics in some fish species and their environs in Eastern Visayas, Philippines. Marine Pollution Bulletin, $167,112312$.

Cardoso, C.W., Silva, M.M.O., Bandeira, A.C., Silva, R.B., Prates, A.P.P.B., Soares, Ê.S., ... \& Ribeiro, G.S. (2022). Haff Disease in Salvador, Brazil, 2016-2021: Attack rate and detection of toxin in fish samples collected during outbreaks and disease surveillance. The Lancet Regional Health-Americas, 5, 100092.

Cardozo, M.V., Borges, C.A., \& Beraldo, L.G. (2018). Shigatoxigenic and atypical enteropathogenic Escherichia coli in fish for human consumption. Brazilian Journal of Microbiology, 49(4), 936-941. https://doi.org/10.1016/j.bjm.2018.02.013.

Cech, G., Sándor, D., \& Molnár, K. (2021). Digenean trematodes in Hungarian freshwater aquacultures. Food and Waterborne Parasitology, 22: e00101.

Chankrachang, S., Sribanditkul, P., \& Subanan, N. (2009). FP52FR-01 Nervous system complications from suspected saxitoxin from the greatest outbreak of puffer fish poisoning in Thailand. Journal of the Neurological Sciences, 285, S140.

Chen, J., Wang, Y., \& Pan, L. (2017a). Separation and purification of two minor typical diarrhetic shellfish poisoning toxins from harmful marine microalgae via combined liquid chromatography with mass spectrometric detection. Journal of the Separation Science, 40(4), 2906-2913.

Chen, J., Zhang, R., Qi, X., Zhou, B., Wang, J., Chen, Y., \& Zhang, H. (2017b). Epidemiology of foodborne disease outbreaks caused by Vibrio parahaemolyticus during 2010-2014 in Zhejiang Province, China. Food Control, 77, 110-115.

Chen, Y., Zhao, Y., \& Zhao, M.M. (2021). Potential health risk assessment of HFRs, PCBs, and OCPs in the Yellow River basin. Environmental Pollution, 75, 116648.

Chinain, M., Gatti, C.M.I., \& Darius, H.T. (2021). Ciguatera poisonings: A global review of occurrences and trends. Harmful Algae, 102:101873.

Costa, P.C., Nascimento, Y.F., Costa, L.R.M., Dias, S.C., Ventura, N.K.O., Yamatogi, R.S., Costa, F.A.A. \& Cossi, M.V.C. (2021). Influence of different periods of pre-slaughter fasting on microbiological quality of bullfrog carcasses 
(Lithobates catesbeianus). Arquivo brasileiro de medicina veterinária e zootecnia. 73 (2), 487-494.

Dallal, M.M.S., Najar, F., Shabani, A.K., Ezoji, K., Shabani, M., Khorasan, M.R.M., \& Jannani, A. (2020). Investigation of the Frequency of Foodborne Botulism in Patients Referred to Loghman Hospital in Tehran City, Iran, From 2008 to 2019. International Journal of Medical Toxicology and Forensic Medicine, 10(2), 28348-28348.

Das, O., Lekshmi, M., \& Kumar, S. (2020). Incidence of norovirus in tropical seafood harbouring fecal indicator bacteria. Marine Pollution Bulletin, 150, 110777.

Davis, C.M., Gupta, R.S., \& Aktas, O.N. (2020). Clinical Management of Seafood Allergy, The Journal of Allergy and Clinical Immunology. In Practice, 8(1), 37-44.

Delgado, C.L., Wada, N., Rosegrant, M.W., Meijer, S. \& Ahmed, $M(2020)$. The future of fish issues and trends to 2020. International Food Policy Research Institute. https://digitalarchive.worldfishcenter.org/bitstream/ha ndle/20.500.12348/2179/WF_358.pdf?sequence1=

Deng, Y., Xu, L. \& Chen, H. (2020). Prevalence, virulence genes, and antimicrobial resistance of Vibrio species isolated from diseased marine fish in South China, Scientific Reports, 10 (1), 1-8.

Di Cola, G., Fantilli, A.C., \& Pisano, M.B. (2021). Foodborne transmission of hepatitis $A$ and hepatitis $E$ viruses: $A$ literature review. International Journal of Food Microbiology, 338, 108986.

Dirks, R.A.M., Jansen, C.C.C., \& Hägele, G. (2021). Quantitative levels of norovirus and hepatitis $A$ virus in bivalve mollusks collected along the food chain in the Netherlands, 2013-2017. International Journal of Food Microbiology, 344, 109089.

Doménech-Sánchez, A., Laso, E., \& Pérez, M J. (2011). Emetic disease caused by Bacillus cereus after consumption of tuna fish in a beach club. Foodborne Pathogens and Disease, 8(7), 835-837.

Don, PS., Ammini, P., \& Nayak, B.B. (2020). Survival behavior of Salmonella enterica in fish and shrimp at different conditions of storage, LWT, 132, 109795. https://doi.org/10.1016/j.Iwt.2020.109795

Donets, M.M., Tsygankov, V.Y., \& Gumovskiy, A.N. (2021). Organochlorine pesticides (OCPs) and polychlorinated biphenyls (PCBs) in Pacific salmon from the Kamchatka Peninsula and Sakhalin Island, Northwest Pacific. Marine Pollution Bulletin, 169, 112498.

EC (2004) Laying down Specific Hygiene Rules for Food of Animal Origin No 853/2004 of the European Parliament and of the Council of 29 April 2004. https://www.fsai.ie/uploadedFiles/Food_Business/Reg8 53_2004.pdf

EFSA (European Food Safety Authority) (2009). Scientific opinion on arsenic in food. EFSA Panel on Contaminants in the Food Chain (CONTAM). EFSA Journal, 7(10), 1351.

Elal Muş, T., \& Çetinkaya, F. (2017). Food poisoning caused by seafood. Turkiye Klinikleri J Food Hyg Technol-Special Topics, 3(3), 200-205.

Elik, A. (2021). Response surface methodology based on central composite design for optimizing temperaturecontrolled ionic liquid-based microextraction for the determination of histamine residual in canned fish products. Journal of Food Composition and Analysis, 98, 103807.

FAO/WHO (2008). Viruses in Food: Scientific Advice to Support Risk Management Activities: Meeting Report. Microbiological Risk Assessment Series (MRA) 13 Rome, Italy. https://apps.who.int/iris/bitstream/handle/10665/440 30/9789241563772_eng.pdf

Friedemann, M. (2016). Ciguatera outbreaks in Germany caused by imported tropical fish. International Journal of Infectious Diseases, 53, 135.

Farradia, Y. \& Sunarno, M.T.D. (2020). Consumer Purchase Decision on Fresh Fish in the New Norm: Preliminary Case Study in Indonesia. Journal of Social Transformation and Regional Development, 2 (1). 52-60.

FDA (2021) Fish and Fishery Products Hazards and Controls Guidance. Fourth Edition department of health and human services public health service food and drug administration center for food safety and applied nutrition office of food safety.

https://www.fda.gov/food/resources-youfood/seafood

Felisiak, K., Szymczak, M., \& Kołakowski, E. (2019). Identification of non-protein nitrogen compounds separated by CZE without derivatization from TCA extract from salted herring meat. Journal of Food Composition and Analysis, 77, 108-114.

Gangs $\varnothing$, T.J. (2021). Top Seafood Consumer Trends. Norwegian Seafood Council, Megatrends. https://www.aqua.cl/wpcontent/uploads/2021/05/Top-Seafood-ConsumerTrends-2021.pdf

Gelis, S., Rueda, M., \& Valero, A. (2020). Shellfish Allergy: Unmet Needs in Diagnosis and Treatment. Journal of Investigational Allergology \& Clinical Immunology, 30(6), 409-420

Ghalyoun, F., \& Alcay, A.U. (2018). Investigation of Rotavirus, Adenovirus and Astrovirus in Mussels and Shrimps Using Multiplex Real-time PCR, Kafkas Universitesi Veteriner Fakültesi Dergisi, 24 (5), 761-767.

Ghosh, G.C., Akter, S.M., \& Islam, R.M, (2021). Microplastics contamination in commercial marine fish from the Bay of Bengal. Regional Studies in Marine Science, 44, 101728.

Gustinelli, A., Menconi, V., \& Prearo, M. (2016). Prevalence of Diphyllobothrium latum (Cestoda: Diphyllobothriidae) plerocercoids in fish species from four Italian lakes and risk for the consumers. International Journal of Food Microbiology, 235, 109-112.

Haarr, A., Mwakalapa, E.B., \& Mmochi, A.J. (2021). Seasonal rainfall affects occurrence of organohalogen contaminants in tropical marine fishes and prawns from Zanzibar, Tanzania. Science of the Total Environment, 774, 145652.

Hafeez, M., Ahmad, I., \& Qureshi, S. (2021). Resistant Clostridium perfringens Isolates from Freshwater Fishes of Dal Lake, Kashmir: A Public Health Concern. National Academy Science Letters, 44, 397-400. https://doi.org/10.1007/s40009-020-01031-w

Hameed, A., Al-Rashida, M., \& Shah, M.R. (2021). Chapter 14 Tetrodotoxin, In. H. Abdul Hameed, M. Al-Rashida, \& M. Raza Shah (Eds.), Visual Guides to Natural Product Synthesis Series, $\alpha$-Tertiary Amines en Route to Natural Products, (pp. 203-221), Elsevier.

Hassan, R., Tecle, S., Adcock, B., Kellis, M., Weiss, J., Saupe, A., ... \& Neil, K. P. (2018). Multistate outbreak of Salmonella Paratyphi B variant $L(+)$ tartrate $(+)$ and Salmonella Weltevreden infections linked to imported frozen raw tuna: USA, March-July 2015. Epidemiology \& Infection, 146(11), 1461-1467.

Hennechart-Collette, C., Dehan, O., \& Laurentie, M. (2021). Detection of norovirus, hepatitis $A$ and hepatitis $E$ 
viruses in multicomponent foodstuffs. International Journal of Food Microbiology, 337, 108931.

Hsu, T.K., Tsai, H.C., \& Hsu, B.M. (2021). Prevalence, enterotoxin-gene profiles, antimicrobial resistance, and genetic diversity of Bacillus cereus group in aquatic environments and shellfish. Science of the Total Environment, 758, 143665.

https://doi.org/10.1016/j.scitotenv.2020.143665.

Huang, Y., Chang, W., \& Hsu, C. (2021). Inactivation of norovirus by atmospheric pressure plasma jet on salmon sashimi. Food Research International, 141, 110108.

Huss, H.H., Reilly, A., Embarek, P.K.B., 2000. Prevention and control of hazard in seafood. Food Control, 11, 149-156.

ICMSF (International Commission on Microbiological Specifications for Foods) (2011). Fish and Seafood Products. In K.M.J. Swanson (ed.), Microorganisms in Foods. (pp. 107-133). Springer, New York, USA.

Ishimaru, M., Muto, Y., \& Nakayama, A. (2019). Determination of biogenic amines in fish meat and fermented foods using column-switching high-performance liquid chromatography with fluorescence detection. Food Analytical Methods, 12(1), 166-175.

Islam, Q.T., Razzak, M.A., Islam, M.A., Bari, M.I., Basher, A., Chowdhury, F.R., ... \& Mebs, D. (2011). Puffer fish poisoning in Bangladesh: clinical and toxicological results from large outbreaks in 2008. Transactions of the Royal Society of Tropical Medicine and Hygiene, 105(2), 74-80.

Janči, T., Valinger, D., \& Kljusurić, J.G. (2017). Determination of histamine in fish by surface enhanced Raman Spectroscopy using silver colloid SERS substrates. Food Chemistry, 224, 48-54.

Ježek P, Škarpa P, LoŠák T, HluŠek J, Jůzl V, Elzner P (2012) Selenium-an important antioxidant in crops biofortification. In: El-Missiry (ed) Antioxidant enzyme. IntechOpen Limited, London, UK, pp 343-368

Jo, S.B., Shin, C.H., \& Shin, Y. (2020). Heavy metal and antibiotic co-resistance in Vibrio parahaemolyticus isolated from shellfish. Marine Pollution Bulletin, 156:111246, https://doi.org/10.1016/j.marpolbul.2020.111246.

Jo, H., Raza, S., \& Farooq, A. (2021). Fish farm effluents as a source of antibiotic resistance gene dissemination on Jeju Island, South Korea, Environmental Pollution, 276, 116764

Karlson, B., Andersen, P., \& Arneborg, L. (2021). Harmful algal blooms and their effects in coastal seas of Northern Europe. Harmful Algae, 102, 101989.

Katikou, P., Georgantelis, D., Sinouris, N., Petsi, A. \& Fotaras, T. (2009). First report on toxicity assessment of the Lessepsian migrant pufferfish Lagocephalus sceleratus (Gmelin, 1789) from European waters (Aegean Sea, Greece). Toxicon, 54(1), 50-5.

Kibria, G., Nugegoda, D. \& Rose, G. (2021). Climate change impacts on pollutants mobilization and interactive effects of climate change and pollutants on toxicity and bioaccumulation of pollutants in estuarine and marine biota and linkage to seafood security, Marine Pollution Bulletin, 167,112364.

Kitano, S., Yamamoto, N. (2020). The role of consumer knowledge, experience, and heterogeneity in fish consumption: Policy lessons from Japan. Journal of Retailing and Consumer Services, 56, 102151.

Kosker, A.R., Özogul, F., Durmus, M., Ucar, Y., Ayas, D., Šimat, V. \& Özogul, Y. (2018). First report on TTX levels of the yellow spotted pufferfish (Torquigener flavimaculosus) in the Mediterranean Sea, Toxicon, 148, 101-106.
Kounnoun, A., Louajri, A., \& Cacciola, F. (2020). Development and validation of a TLC-Densitometry method for histamine monitoring in fish and fishery products. Molecules, 25 (16), 3611.

Kris-Etherton, P., M., Harris, W.S. \& Appel, L.J. (2002). Fish consumption, fish oil, omega-3 fatty acids, and cardiovascular disease. Circulition, 19, 2747-2757.

Kusche, H., \& Hanel, R. (2021). Consumers of mislabeled tropical fish exhibit increased risks of ciguatera intoxication: A report on substitution patterns in fish imported at Frankfurt Airport, Germany. Food Control, 121,107647

Lampila, L.E., \& McMillin, K.W. (2012). Major microbial hazards associated with packaged seafood. In J.P. Kerry (ed.), Advances in Meat, Poultry and Seafood Packaging, (pp 59-85). Woodhead Publishing.

Lassen, S.G., Ethelberg, S., Björkman, J.T., Jensen, T., Sørensen, G., Jensen, A.K., ... \& Mølbak, K. (2016). Two listeria outbreaks caused by smoked fish consumption-using whole-genome sequencing for outbreak investigations. Clinical Microbiology and Infection, 22(7), 620-624.

Li, H., Wei, X., \& Gu, C. (2018). A Dual Functional Cardiomyocyte-based Hybrid-biosensor for the Detection of Diarrhetic Shellfish Poisoning and Paralytic Shellfish Poisoning Toxins. Analytical Science, 34 (8), 893-900.

Li, J., \& Persson, K.M. (2020). Quick detection method for paralytic shellfish toxins (PSTs) monitoring in freshwater - A review. Chemosphere, 265, 128591.

Llewellyn, L.E., (2010). Revisiting the association between sea surface temperature and the epidemiology of fish poisoning in the South Pacific: Reassessing the link between ciguatera and climate change, Toxicon, 56(5), 691-697.

Lotze, H.K., Bryndum-Buchholz, A., \& Boyce, D.G. (2021). Chapter 8 - Effects of climate change on food production In. Letcher, T.M (Ed.), The Impacts of Climate Change, (205-231), Elsevier.

Lunestad, B.T., Levsen, A., \& Rosnes, J.T. (2011). Tracing pathogens in fish production chains. In S. Brul, P.M. Fratamico \& T.A. McMeckin (eds.), Tracing Pathogens in the Food Chain. (pp. 433-464). Woodhead Publishing.

Markic, A., Gaertner, J.C., \& Gaertner-Mazouni, N. (2020). Plastic ingestion by marine fish in the wild. Critical Reviews in Environmental Science and Technology, 50 (7), 657-697.

McMahon, T., Silke, J. (1996). West coast of Ireland; winter toxicity of unknown aetiology in mussels. The Intergovernmental Oceanographic Commission of UNESC Harmful Algae News, An IOC Newsletter on toxic algae and algal blooms, 14:2.

Min, M., Bai, L., \& Peng, X. (2021). An Outbreak of Botulinum Types A, B, and E Associated with Vacuum-Packaged Salted Fish and Ham. The Journal of Emergency Medicine, 29, 760-763. https://doi.org/10.1016/j.jemermed.2020.12.006.

Min, M., Bai, L., Peng, X., Guo, L., Wan, K., \& Qiu, Z. (2021). An Outbreak of Botulinum Types A, B, and E Associated with Vacuum-Packaged Salted Fish and Ham. The Journal of Emergency Medicine, 60(6), 760-763.

Mol, S., Cosansu, S., \& Alakavuk, D.U. (2010). Survival of Salmonella Enteritidis during salting and drying of horse mackerel (Trachurus trachurus) fillets. International Journal of Food Microbiology, 30, 139 (1-2), 36-40. 
Mol, S., Kahraman, A.E., \& Ulusoy, S. (2019). Potential Health Risks of Heavy Metals to the Turkish and Greek Populations via Consumption of Spiny Dogfish and Thornback Ray from the Sea of Marmara. Turkish Journal of Fisheries and Aquatic Sciences, 19, (2), 19-27.

Morin, E., Gatti, C., Bambridge, T., \& Chinain, M. (2016). Ciguatera fish poisoning incidence, health costs and risk perception on Moorea Island (Society archipelago, French Polynesia). Harmful Algae, 60, 1-10.

Myrmel, M., Berg, E.M., \& Rimstad, E. (2004). Detection of enteric viruses in shellfish from the Norwegian coast. Applied and Environmental Microbiology, 70, 2678-2684.

Nick, Y., Charlotte, R., \& Rachel, K. (2019). Outbreak of diarrhetic shellfish poisoning associated with consumption of mussels, United Kingdom, May to June 2019. Euro Surveillance, 24(35), 1900513.

Nicholas V.C., Ralston, J., \& Kaneko, J. (2019). Selenium health benefit values provide a reliable index of seafood benefits vs. risks. Journal of Trace Elements in Medicine and Biology, 55, 50-57.

Nurnadia, A.A., Azrina, A., Amin, I., Mohd Yunus, A.S. \& Mohd Izuan Effendi, H. (2013). Mineral contents of selected marine fish and shellfish from the west coast of Peninsular Malaysia. International Food Research Journal 20(1): 431-437.

Ochi, N. (2019). Simultaneous determination of eight underivatized biogenic amines in salted mackerel fillet by ion-pair solid-phase extraction and volatile ion-pair reversed-phase liquid chromatography-tandem mass spectrometry. Journal of Chromatography A, 1601, 115120.

Onmaz, N.E., Yildirim, Y., \& Karadal, F. (2020). Escherichia coli O157 in fish: Prevalence, antimicrobial resistance, biofilm formation capacity, and molecular characterization. LWT, 133, 109940.

Pal, M. (2018). Is Aeromonas hydrophila a potential pathogen of food safety concern? Journal of Food Microbiology, 2(1), 1-2.

Parvin, F., Jannat, S., \& Tareq, S.M. (2021). Abundance, characteristics and variation of microplastics in different freshwater fish species from Bangladesh. Science of the Total Environment, 784, 147137.

Pavio, N., Kooh, P., \& Cadavez, V. (2021). Risk factors for sporadic hepatitis $E$ infection: a systematic review and meta-analysis. Microbial Risk Analysis, 17, 100129.

Podolska, M., Pawlikowski, B., \& Nadolna-Ałtyn, K. (2019). How effective is freezing at killing Anisakis simplex, Pseudoterranova krabbei, and P. decipiens larvae? An experimental evaluation of time-temperature conditions. Parasitology Resource, 118(7), 2139-2147.

Price, R.J. (1999) HACCP for delicatessens and meat, poultry and seafood retailers. In: Pearson AM, Dutson TR (eds) HACCP in meat, poultry and fish processing. An Aspen Publication, p 182-229.

Rasetti-Escargueil, C., Lemichez, E. \& Popoff., M.R. (2020). Public Health Risk Associated with Botulism as Foodborne Zoonoses". Toxins 12: 1-17.

Ralston, N.V.C., Ralston, C.R., Blackwell, J.L., Raymond, L.J. (2008). Dietary and tissue selenium in relation to methylmercury toxicity. Neurotoxicology, 29:802-811

Rasta, M., Sattari, M., \& Taleshi, M.S. (2021). Microplastics in different tissues of some commercially important fish species from Anzali Wetland in the Southwest Caspian Sea, Northern Iran. Marine Pollution Bulletin, 169,112479 .
Riaz, R., De Wit, C.A., \& Malik, R.N. (2021). Persistent organic pollutants (POPs) in fish species from different lakes of the lesser Himalayan region (LHR), Pakistan: The influence of proximal sources in distribution of POPs. Science of the Total Environment, 760, 143351.

Rosnes, J.T., Skåra, T., \& Skipnes, D. (2011). Recent advances in minimal heat processing of fish: Effects on microbiological activity and safety. Food Bioprocess Technoogy, 4, 833-848.

Rothe, C., \& Katchanov, J. (2020). A 40-Year-Old Woman from Thailand and Her Brother-in-Law with Severe Headache. In R. Camilla (Ed.), Clinical Cases in Tropical Medicine (Second Edition), (pp. 176-178). Elsevier.

Rowland-Pilgrim, S., Swan, S.C., \& O'Neill, A. (2019). Variability of Amnesic Shellfish Toxin and Pseudo-nitzschia occurrence in bivalve molluscs and water samplesAnalysis of ten years of the official control monitoring programme. Harmful Algae, 87, 101623.

Schroeder, G., Bates, S.S., \& Spallino, J. (2015). Amnesic shellfish poisoning: Emergency medical management. Journal of Marine Science: Research \& Development, 6, 179.

Semenko, N., Mokhort, H., Sokolovska, O., Kolesnikova, O., Kuzin, I. \& Saylors, K. (2021) Foodborne Pathogens and Disease 18 (4) 260-266.

Sikorski, Z.E., Kolakowska, A., \& Burt, J.R. (1990). Postharvest biochemical and microbial changes. In Z.E. Sikorski (ed.), Seafood: resources nutritional composition and preservation. CRC Press Boca Raton, Florida, p 55-76.

Simmons, M.A. (2007). Tetrodotoxin. In: Enna, S.J. \& Bylund, D.B (eds.) xPharm: The Comprehensive Pharmacology Reference, Elsevier, p 1-4.

Singh, R.P., Mishra, S., \& Das, A.P. (2020). Synthetic microfibers: Pollution toxicity and remediation. Chemosphere, 257, 127199.

Sony, M., Sumithra, T.G. \& Anushree, V.N. (2021). Antimicrobial resistance and virulence characteristics of Vibrio vulnificus, Vibrio parahaemolyticus and Vibrio harveyi from natural disease outbreaks of marine/estuarine fishes. Aquaculture. 539, 736608.

$\mathrm{Su}, \mathrm{C} .$, \& Chen, L. (2020). Virulence, resistance, and genetic diversity of Vibrio parahaemolyticus recovered from commonly consumed aquatic products in Shanghai, China. Marine Pollution Bulletin, 160, 111554. https://doi.org/10.1016/j.marpolbul.2020.111554.

Tao, L., Zhang, Y., \& Wu, J. (2019). Biomagnification of PBDEs and alternative brominated flame retardants in a predatory fish: Using fatty acid signature as a primer. Environment International, 127, 226-232.

Tham, W., Ericsson, H., Loncarevic, S., Unnerstad, H., \& Danielsson-Tham, M.L. (2000). Lessons from an outbreak of listeriosis related to vacuum-packed gravad and coldsmoked fish. International journal of food microbiology, 62(3), 173-175.

Tian, Y., Du, L., \& Zhu, P. (2021). Recent progress in micro/nano biosensors for shellfish toxin detection. Biosensors and Bioelectronics, 176, 112899.

Tirado, M.C., Clarke, R., \& Jaykus, L.A. (2010). Climate change and food safety: A review. Food Research International, 43(7), 1745-1765.

Toner, K., \& Midway, S.R. (2021). Historic fish samples from the Southeast USA lack microplastics. Science of the Total Environment, 776, 145923.

Turgut, N. (2021). Gıdalarda Escherichia coli 0157:H7 Yaygınlığının Riskleri ve Kontrolü Escherichia coli 0157: 
H7 Prevalence and Control in Foods. Adnan Menderes Üniversitesi Sağlık Bilimleri Fakültesi Dergisi, 5(1); 101114.

Ulusoy, S., Mol, S., \& Karakulak, F.S. (2019). Selenium-Mercury Balance in Commercial Fish Species from the Turkish Waters. Biological Trace Element Research, 191, 207213.

US EPA (2017). EPA-FDA advice about eating fish and shellfish. https://www.epa.gov/fish-tech/epa-fda-advice-abouteating-fish-and-shellfish

Vale, P., Ribeiro, I., \& Rodrigues, S.M (2021). Workflow of the pre-chromatographic 'Lawrence' method for bivalves contaminated with Gymnodinium catenatum's paralytic shellfish poisoning toxins. Food Control, 126, 108081.

Velebit, B., Djordjevic, V., \& Milojevic, L. (2019). The common foodborne viruses: A review. IOP Conference Series: Earth and Environmental Science, Volume 333, The $60^{\text {th }}$ International Meat Industry Conference MEATCON2019 22-25 September 2019, Kopaonik-Serbia.

Wang, L., Fu, Z., Deng, W., Zhu, S., Zhang, C., \& Zhang, W. (2021). Maternal fish and shellfish consumption and preterm birth: A retrospective study in urban China. British Journal of Nutrition, 1-9.

Wang, X., Lin, Y., Zheng, Y. \& Meng, F. (2022). Antibiotics in mariculture systems: A review of occurrence, environmental behavior, and ecological effects, Environmental Pollution, 293,118541.

Whitelaw, B.L., Cooke, I.R., \& Finn, J. (2019). The evolution and origin of tetrodotoxin acquisition in the blue-ringed octopus (genus Hapalochlaena). Aquatic Toxicology, 206, 114-122.

WHO (2021) Antibiotic resistance. https://www.who.int/news-room/factsheets/detail/antibiotic-resistance

Wong, C.K., Hung, P., Lee, K.L., \& Kam, K.M. (2005). Study of an outbreak of ciguatera fish poisoning in Hong Kong. Toxicon, 46(5), 563-571.

Yilmaz, U.T., \& Inan, D. (2015). Quantification of histamine in various fish samples using square wave stripping voltammetric method. Journal of Food Science and Technology, 52(10), 6671-6678. 